\title{
Turbidite chronostratigraphy off Algiers, central Algerian margin: A key for reconstructing Holocene paleo-earthquake cycles
}

\author{
Babonneau Nathalie ${ }^{1,}{ }^{*}$, Cattaneo Antonio ${ }^{2}$, Ratzov Gueorgui ${ }^{3}$, Déverchère Jacques ${ }^{1}$, \\ Yelles-Chaouche Abdelkarim ${ }^{4}$, Lateb Tassadit ${ }^{4}$, Bachir Roza Si ${ }^{4}$
}

${ }^{1}$ Université de Brest, IUEM, CNRS UMR 6538 Domaines Océaniques, Place N. Copernic, 29280, Plouzané, France

${ }^{2}$ IFREMER, Institut Carnot EDROME, Géosciences Marines, BP.70, 29280 Plouzané, France

${ }^{3}$ Géoazur, Université de Nice Sophia-Antipolis, CNRS, Observatoire de la Côte d'Azur, 250 rue Albert Einstein, 06560, Valbonne, France

${ }^{4}$ CRAAG, BP 63, Route de l'Observatoire, Bouzareah, 16340 Algiers, Algeria

*Corresponding author : Nathalie Babonneau, email address : nathalie.babonneau@univ-brest.fr

\begin{abstract}
:
Northern Algeria is threatened by moderate to large magnitude earthquakes resulting from the slow convergence between the African and European plates. Main active faults are located offshore along the Algerian coast, as exemplified by the $2003 \mathrm{Mw} 6.9$ Boumerdès earthquake. This event triggered numerous and widespread turbidity currents over $\sim 150 \mathrm{~km}$ along strike in the Algerian basin (reaching $2800 \mathrm{~m}$ of water depth) and demonstrates the multi-source and multi-path characteristics of earthquaketriggered turbidity flows along this margin segment.
\end{abstract}

We rely on the sedimentological analysis of five cores located at the toe of the Algiers margin, close to the 2003 cable break sites, to explore the potential for Holocene turbidite paleoseismology. Radiocarbon measurements provide age models for hemipelagic sediments. Based on sedimentary facies identification, analysis of depositional sequences (stacking pattern) and a stratigraphic framework established by age models, a first correlation of turbidites between the 5 cores is attempted. The number of turbidites is constant at the base of the continental slope and decreases seawards (over 80 $\mathrm{km}$ away from the coast). From turbidite correlations, 36 synchronous events are identified along the Algiers margin segment over the last $9 \mathrm{kyr}$, and are tentatively interpreted as seismically triggered, providing a $250 \mathrm{yr}$ long mean recurrence interval.

The main historical earthquakes in the Algiers area (2003, 1716 and 1365 AD) reasonably correlate with three out of the four last turbidites, strengthening the hypothesis that turbidites are suitable markers for Holocene paleoseismology. Recurrence intervals of turbidites range between 50 and $900 \mathrm{yr}$, defining quiescence periods exceeding $450 \mathrm{yr}$. Three quiescence periods lasting about 800,1400 and $500 \mathrm{yr}$ (76.2 ka BP, 5.4-4 ka BP, and 1.5-1 ka BP, respectively) support irregular earthquake cycling. Earthquake-triggered turbidites are more frequent in the study area than in the western adjacent margin segment (offshore El Asnam). This higher frequency could arise from the location of the seismogenic 
faults beneath the continental slope, whereas they are located several tenths of kilometers onland in the El Asnam area, implying less instabilities of the submarine slope.

Keywords : Algerian margin, marine paleoseismology, turbidite, Holocene 


\section{Introduction}

Paleoseismology aims at building long time series of earthquakes using either on-fault (measurement and quantification of slip history within the fault plane) or off-fault evidences (history of the sedimentary deposits triggered by large fault ruptures in their vicinity) (Gràcia et al., 2013, and references therein; McCalpin, 2009). Indeed, long paleo-earthquake records are crucial to better assess earthquake recurrences, and numerous seismic cycles over long time spans are necessary to set up reliable earthquake occurrence and cyclicity models. In subaqueous environments, a few pioneer works revealed the good potential of lacustrine and marine sedimentary deposits to directly or indirectly record large earthquakes (Adams, 1990; Sims, 1973, 1975). Since about 15 years ago, turbidite paleoseismology has become a powerful and widely used approach to indirectly assess long time series of earthquakes, especially in subduction zones, because strong seafloor shaking during large earthquakes (approximately $\mathrm{M}>6.5-7$ ) generally promotes multiple and widespread turbidity currents across continental margins (e.g., Goldfinger et al., 2003; Gràcia et al., 2010, Polonia et al., 2013; Pouderoux et al., 2014; Bernhardt et al., 2015). Long time series are even more important in slowly deforming areas (convergence rate $<1 \mathrm{~cm} / \mathrm{yr}$ ) since historical records are often scarce or missing there and because recurrence intervals may outpass a thousand of years. However, identifying earthquakes as the triggering mechanism of turbidites is not straightforward (e.g. Gorsline et al., 2000; Pouderoux et al., 2014, Sumner et al., 2013) and requires establishing synchronicity between events over long distances and across independent sedimentary systems (Goldfinger et al., 2003, 2007; Gràcia et al., 2010).

The link between earthquakes and submarine gravitational processes is suggested in several works off Algeria (Babonneau et al., 2012; Cattaneo et al., 2010; Dan et al, 2010; DanUnterseh at al., 2011; Giresse et al., 2009). First applications of turbidite paleoseismology were recently performed on sediment cores collected in the deep basin (> $2300 \mathrm{~m}$ water depths) along the western Algerian margin, at the Africa-Eurasia plate boundary (Cattaneo et 
al., 2012; Ratzov et al., 2015). Off western Algeria, 13 paleo-earthquakes were identified over the last $8 \mathrm{kyr}$ (mean recurrence interval of $660 \mathrm{yr}$ ) and are grouped within three "bursts" of seismic activity (3, 4 or 6 events occurring every 300-600 yr) separated by two $\sim 1600$ yr long quiescence periods (Ratzov et al., 2015). Such pattern of cycle irregularities supports the concept of seismic supercycles, as was first evidenced in subduction zones (Goldfinger et al., 2013), and may substantially modify probability models of earthquake recurrence.

In this study, we present the first estimate of earthquake recurrences over the Holocene in the central Algerian margin from the analysis and space/time correlations of sediment cores sampled off Algiers, the capital of Algeria. This highly populated area underwent a $M_{w} 6.8$ damaging earthquake on May 21, 2003 (Delouis et al., 2004; Meghraoui et al., 2004, Yelles et al., 2004; Semmane et al., 2005), which was followed by turbidity currents responsible for 29 submarine cable breaks at the toe of the continental slope (Cattaneo et al., 2012). Piston cores were collected along the Algerian margin during four oceanographic cruises conducted between 2003 and 2007: MARADJA (doi:10.17600/3020100), PRISMA (doi: 10.17600/4200150), MARADJA2 (doi:10.17600/5020080) and PRISME (doi: 10.17600/7010090). This study is mainly based on the analysis of five selected piston cores located in the basin at the base of the continental slope of the Algiers margin (> $2300 \mathrm{~m}$ water depth), close to the 2003 AD cable break sites. We aim to identify and date turbidites correlated between these sites in order to (1) compare the most recent turbidites with historical earthquakes of the Algiers region (including earthquakes of Algiers 1365 AD and 1716 AD), Blida, 1825 AD, Mouzaia, 1867 AD and Boumerdès, 2003 AD), (2) build a tentative paleo-earthquake record, and (3) estimate recurrence intervals over the Holocene.

\section{Geological setting}




\subsection{Seismo-tectonic setting of the Algerian margin}

The Algerian margin is a Cenozoic passive margin (Fig. 1), located at the diffuse plate boundary between Eurasia and Africa, presently reactivated in compression (Stich et al., 2006). The convergence is distributed both onland and offshore and is dominated by ESEWNW-trending shortening structures, corresponding to active thrusts and folds offshore (Déverchère et al., 2005; Domzig et al., 2006; Kherroubi et al., 2009, Yelles et al., 2009). These structures are associated to crustal shortening at a present-day rate of $2 \mathrm{~mm} / \mathrm{yr}$ or less (Serpelloni et al., 2007; Palano et al., 2015), responsible for moderate to large earthquakes $\left(\mathrm{M}_{\mathrm{w}}<7.5\right)$ (Ambraseys and Vogt, 1988; Stich et al., 2006). The Algerian margin is among the most seismically active areas of the Western Mediterranean. The catalogue of historical earthquakes (856-2008 AD) reports 22 earthquakes of estimated magnitude > 6 near the Algerian coast (Hamdache et al., 2010). Magnitudes of historical earthquakes are interpreted from the historical accounts, but these might be biased depending on the population of each area. True magnitudes and epicenters are provided only for instrumental seismology, i.e. the last century.

\subsection{Morphology and structure of the Algerian margin}

The Algerian continental slope is steep $\left(>4^{\circ}\right)$ and strongly incised by numerous canyons and escarpments (Fig. 1). The escarpments are related to active tectonic structures identified by Plio-Quaternary growth strata developing above ramps (Déverchère et al., 2005; Domzig et al., 2006; Kherroubi et al., 2009; Strzerzynski et al., 2010). In the deep basin, numerous bathymetric highs are visible with various shapes and orientations: the largest elongated highs are also linked to active folds and thrusts, whereas the narrowest are associated to Messinian salt diapirs (Domzig et al., 2006). Numerous submarine landslides were identified along these structures as well as along the continental slope and in the basin (Dan-Unterseh et al., 2011). They are expressed by small scars (kilometer-scale or less) and outcropping or buried mass- 
transport deposits, well defined on echosounder profiles and characterised by sediment coring (Cattaneo et al., 2010, Dan et al., 2009, 2010, Nouguès et al., 2010).

The central part of the Algerian margin (Fig. 2) can be divided into two areas: the western area from the Khayr Al Din shelf to the Algiers canyon (Algiers area), and the eastern area from the east of the Algiers canyon to the front of Dellys city (Dellys area). The shelf is narrow, less than $10 \mathrm{~km}$ wide, except at the Khayr Al Din shelf where it is up to $20 \mathrm{~km}$ wide. The base of the continental slope is at about $2500 \mathrm{~m}$ water depth (Fig. 2).

In Dellys area (Fig. 2), the continental slope is irregular (gradient $<5^{\circ}$ ), with successions of scarps and plateaus, interpreted as the seafloor deformation of the margin along SW-NE northward-verging thrusts (Déverchère et al., 2005; Domzig et al., 2006). The fault activity builds two types of morphological features (Fig. 2): (1) scarps along the upper and lower slope and (2) asymmetric anticline rises associated to blind thrusts (Déverchère et al., 2005, 2010; Strzerzynski et al., 2010). The Dellys slope is incised by a succession of welldeveloped canyons (Fig. 2).

In the Algiers area, the continental slope exhibits steep gradients (about $8-10^{\circ}$ ) incised by numerous gullies and small canyons (Fig. 2). The only well-incised canyon is the Algiers canyon, containing two main tributaries in its upper part and a strong deviation of its pathway near their confluence. At the base of the slope, the morphology shows a series of W-E elongated bathymetric highs or ridges induced by the growth of asymmetric anticlines. The Algiers canyon outlet is deviated westwards into a 4 x $15 \mathrm{~km}$ depocentre, named the Algiers corridor (fig. 2), corresponding to a piggy-back basin behind the Algiers ridge. In the deepest part of the basin, the morphology of the seafloor is complex, combining effects of fault ramps and diapirs of Messinian salt (Fig. 2). Salt diapirs form isolated mounts and narrow elongated highs (Déverchère et al., 2005; Yelles et al., 2009).

\subsection{Historical seismicity in the Algiers area}


Three large earthquakes are reported in the Algiers area over the last thousand years: in 1365 AD and 1716 AD for the historical period (Hamdache et al., 2010; Ayadi and Bezzeghoud, 2015) and in $2003 \mathrm{AD}$ for the instrumental one. The 1365 AD Algiers earthquake is considered the most destructive event before the 2003 Boumerdès earthquake. In 1365 AD, Algiers was completely destroyed and a large part of the city was flooded, indicating a significant tsunami (Ambraseys and Vogt, 1988; Ayadi and Bezzeghoud, 2015). Two other historical earthquakes caused damage close to the city of Blida $(50 \mathrm{~km}$ southwest from Algiers): the 1825 AD (Blida) and 1867 AD (Mouzaia) events (Fig. 1).

The 2003 AD Boumerdès earthquake (Magnitude 6.8) caused significant damage and over 2300 casualties (Harbi et al., 2007). The length of the rupture zone was estimated at $\sim 60 \mathrm{~km}$ in a $\mathrm{N} 65^{\circ} \mathrm{E}$ strike, and the rupture depth was proposed between 5 and $13 \mathrm{~km}$ (Bounif et al., 2004; Delouis et al., 2004; Meghraoui et al., 2004; Yelles et al., 2004; Semmane et al., 2005). Ayadi et al. (2008) propose that the rupture reached the surface offshore near the coastline, whereas Déverchère et al. (2005, 2010) and Mahsas et al. (2008) favour a flat-ramp geometry, with a submarine fault scarp at 5-10 km from the coastline. After this earthquake, a sea retreat was observed along parts of the Algerian coastline, while a tsunami was recorded in several harbours across the western Mediterranean Sea, reaching $~ 2 \mathrm{~m}$ height at the Balearic Islands (Alasset et al., 2006).

\subsection{Earthquakes and turbidity currents on the Algerian margin}

Submarine cable breaks were reported minutes to hours after three earthquakes along the Algerian margin. The first submarine cable breaks occurred off western Algeria (Kramis area) owing to turbidity currents triggered by the $1954 \mathrm{AD}, \mathrm{M}_{\mathrm{w}} 6.7$ Orléansville earthquake (Heezen and Ewing, 1955). The nearby 1980 AD, $\mathrm{M}_{\mathrm{w}} 7.3 \mathrm{El}$ Asnam earthquake did not break submarine cable in the Kramis area: a single cable break is reported on the upper continental 
slope on the cable connected to Algiers (El-Robrini et al., 1980), suggesting submarine instability of the steepest slope.

In 2003, the Boumerdès earthquake triggered large turbidity currents breaking cables 29 times at the base of the continental slope along a $150 \mathrm{~km}$ wide section of the margin (Fig. 3). Cable breaks occurred at the outlets of submarine canyons and in areas of turbiditic levee overspills (Cattaneo et al., 2012). Seafloor morphology, backscatter reflectivity and deep-towed sidescan sonar have highlighted the imprints of this event, allowing a reconstruction of the possible sources and pathways of turbidity currents (Fig. 3). They demonstrate the multisource and multi-path character of the 2003 turbiditic event (Cattaneo et al., 2012).

\section{Data and methods}

We base this study on the analysis of sediment cores and geophysical data acquired during the MARADJA2/SAMRA 2005 and PRISME 2007 cruises.

\subsection{Geophysical data: bathymetry and seismic profiles}

The geophysical data include multichannel seismic profiles, Chirp echosounder profiles, Simrad EM300 multibeam bathymetry and backscatter reflectivity data and deep-tow SAR side-scan sonar data. The multibeam bathymetry data were used to construct a DEM, characterized by a horizontal resolution of $50 \mathrm{~m}$ and a vertical accuracy of $2 \mathrm{~m}(1 \%$ of the water depth). The high-resolution multichannel seismic profiles were acquired at $5 \mathrm{kn}$ using 6 mini GI air-guns (mean frequency $120 \mathrm{~Hz}$ ) shooting at a rate of $10 \mathrm{~s}$ and a $2500 \mathrm{~m}$ long 96channels streamer. The vertical resolution of the seismic data is $\sim 10 \mathrm{~m}$.

\subsection{Sedimentological data}


Sixteen sediment cores were recovered in water depths between 2300 and $2800 \mathrm{~m}$ during the MARADJA2 and PRISME surveys using two types of coring systems: a 15 or $20 \mathrm{~m}$ long Kullenberg piston corer and the Ifremer Interface sediment corer ( $1 \mathrm{~m}$ long). X-ray images of the cores were obtained with the SCOPIX system of Bordeaux University. The Geotek MultiSensor Core Logging system was used to obtain physical measurements of gamma density, P-wave velocity and magnetic susceptibility. The major-element composition was obtained with an Avaatech XRF Core-Scanner analysed at 10 and $30 \mathrm{kV}$. The selected measurement area was $8 \mathrm{~mm}$ long and the step-size was set at $1 \mathrm{~cm}$. Sediment cores were sampled for grain-size analyses using a Coulter LS230 laser micro-granulometer, for the 0.01-2000 $\mu \mathrm{m}$ fraction. Sample intervals were adapted and chosen according to facies variability.

In this paper, we present the sedimentological logs of five piston cores (Fig. 2). From west to east, cores PSM-KS21, PSM-KS23 and PSM-KS27 are distal, located further than $40 \mathrm{~km}$ seaward from the coast, whereas KMDJ18 and KMDJ20 are considered as proximal, located at less than $30 \mathrm{~km}$ from the coast, on the southern side of the Algiers ridge (Fig. 2). At the site of KMDJ20, we also collected a short interface core IMDJ20 (Table 1).

The five cores offer the opportunity to study well-preserved, long and continuous successions of turbidites alternating with hemipelagites. The preservation of hemipelagic layers between turbidites is crucial to obtain radiocarbon ages and to establish an accurate chronostratigraphic framework (age models).

Tops of long piston cores are often poorly preserved during coring, especially in cores KMDJ18 and KMDJ20. Cores PSM-KS21, PSM-KS23 and PSM-KS27 are less affected by this problem thanks to the use of a more efficient coring tool onboard R/V L'Atalante (Campaign PRISME) compared to R/V Le Suroit (Campaign MARADJA2, cores KMDJ18 and KMDJ20). 


\subsection{Sedimentary facies determination}

Sedimentary facies and their boundaries were determined with detailed sedimentological analysis (description, photographs, X-ray images, grain size), major elements and physical parameters variations. The identification of the base of turbidites is direct because of the sharp and often erosional contact of coarse sediment above muddy hemipelagic layers. Erosion thickness of the underlying deposits cannot be accurately estimated. It varies depending on the cohesion and compaction of the underlying sediments and on the physical characteristics of the turbidity currents (velocity, density).

The top of turbidites is often difficult to identify because of the progressive change of facies from turbidite muddy interval (settling of the turbidity current fine-grained tail) to the true hemipelagic sediment. Moreover, the interface between the top of turbidites and hemipelagites is sometimes bioturbated, with a poorly defined interval where two deposits are mixed. The accurate binocular analysis of microfacies can provide a discrimination between reworked material (broken foraminifera and terrigenous particles such as silt), and true hemipelagites with entire foraminifera and less silt. Analyses of grain-size spectra (laser granulometry) and chemical composition (XRF core-scanner data) are not always discriminant. In our cores, the detailed visual description of sedimentary facies is more effective. The error associated to the position of the upper boundary of turbidite may in some cases exceed $1 \mathrm{~cm}$. Erosional contacts at the base of turbidites and the uncertainties of the determination of the tops imply temporal discontinuities or errors in age determinations, and affect the accuracy of age models.

\subsection{Chronostratigraphy}


Chronostratigraphic data were obtained using AMS radiocarbon ages from planktonic foraminifera (Table 2). We selected samples in hemipelagic intervals below the base of the turbidite and picked out at least $10 \mathrm{mg}$ of planktonic foraminifer specimens (Globigerinoides ruber, Globigerinoides sacculifer, Globigerinoides bulloides) from the $>150 \mu \mathrm{m}$ fraction (after washing and sieving at $63 \mu \mathrm{m}$ ). These samples were then dated at the LMC14 in Saclay, France.

Radiocarbon ages were calibrated with Oxcal software (OxCal v.4.2.4; Bronk Ramsey, 2008), using the MARINE13 calibration Curve (Reimer et al., 2013). Age models are based on the extrapolation of sedimentation rates of hemipelagic deposits, removing turbidite deposits, which are geologically instantaneous events. Considering (1) the imprecision of radiocarbon measurements and calibrations, (2) the uncertainties of the determination of the top of the turbidite deposits, (3) short-term variations in sedimentation rates, and (4) the probable removal of a certain amount of hemipelagic sediments at the base of the turbidites (due to erosion), a simple linear age model between radiocarbon ages is insufficient. To propagate uncertainties, age models are built using the OxCal software with a $\Delta \mathrm{R}=0+/-50$ that we chose for the study area, and (2) uses a Poisson law as random process (P_Sequence). The input parameters to generate the sequence model are the uncalibrated radiocarbon ages with their corrected depths, corresponding to depths of hemipelagic sediments without turbidite deposits. The regularity of sedimentation is determined by the $k$ parameter, with higher $k$ values corresponding to small changes of sedimentation rate. In this work, we estimate that variations in sedimentation rate may be significant (e.g. Giresse et al., 2009), and all age models were computed with $k=1$. Results of OxCal models provide an estimation of probable ages of all the turbidites described in the cores. Age models are represented by graphs of modelled ages in ka BP versus hemipelagic depths in core in cm (cumulated thicknesses of 
hemipelagic sediment from the seafloor), where the ages of the turbidites are represented by a distribution diagram of potential ages.

\section{Results}

\subsection{Sedimentary architecture of Quaternary deposits}

Seismic lines Mdjs25 and Mdjs26 (Figs. 4 and 5) run from the lower continental slope to the deep basin in the Algiers area. The penetration of the seismic lines is limited to the PlioQuaternary sediments (Domzig et al., 2006).

Seismic line Mdjs25 (Fig. 5a) crosses the lower slope, the Algiers corridor, the Algiers Ridge, a $3 \mathrm{~km}$ wide erosional scarp and a second ridge down to the deep basin (Fig. 4). The deep structure shows two successive anticlines (Fig. 5a). Two types of undulations are identified. The first type is visible near the surface without deep expression: they correspond to sedimentary structures such as sediment waves, channels or other sedimentary features (lobe deposits, levees), typically observed in turbidite systems (e.g. Migeon et al., 2001). The second type of undulation presents deep roots with strong deformation of the reflectors above transparent seismic facies. These deformations are associated to salt diapirism. The sedimentary succession shows different seismic facies: stratified seismic units and chaotic seismic units with various thicknesses and continuities (Fig. 5). Sedimentary units are thicker in morphological lows, where large amounts of sediments coming from gravity currents are trapped. Erosion of the northern flanks of ridges is testified by the truncation of reflectors.

Seismic line Mdjs26 (Fig. 5b) shows that the Algiers corridor corresponds to a syncline. The deep structure of the Algiers ridge consists of the coalescence of the two anticlines described in Mdjs25 (Fig. 5a). A large chaotic unit, recognized on both profiles (Fig. 5), probably corresponds to a giant mass-transport deposit, as described by Dan et al. (2010) and Cattaneo et al. (2010), but the origin and the composition of this unit are unknown. A diapir is visible at 
the top of this mass-transport deposit. Such mass-transport deposits are typically composed of under-compacted sediments that can be remobilized, e.g. during a subsequent earthquake, leading to the formation of diapirs or mud/sand volcanoes (Moernaut et al., 2009).

These two seismic lines illustrate the control of tectonic structures on the seafloor morphology in the central part of the Algerian margin. Erosion and gravity flows are highly dominant in terms of sedimentary processes and continuously reshape reliefs formed by tectonics. No well-developed sedimentary system is observed as deep-sea fans with channellevee systems or organized lobe accumulations. Sediments transported by turbidity currents are partly trapped inside the Algiers corridor and fine-suspended sediments can extend to the deepest area, as exemplified by the reconstruction of the 2003 turbiditic event (Cattaneo et al., 2012).

\subsection{Sedimentary facies}

Four types of sedimentary deposits are identified in sediment cores: hemipelagic layers, finegrained turbidites, sandy turbidites, and homogenites (Figs. 6 and 7). All the cores are dominated by alternating hemipelagic layers (green in fig. 6) and fine-grained turbidites (yellow in fig. 6), with occasional sandy turbidites (orange in fig. 6). Homogenite facies is only observed once in three different cores (grey in fig. 6).

- Hemipelagic layers are homogeneous bioturbated deposits (Fig. 7), composed of pelagic beige clay with a small content of fine-grained silt and contain foraminifera and pteropods.

- Fine-grained turbidites are distinct beds with a sharp base and a normal grading (Fig. 7). Their thickness ranges from $2-3$ to $20-30 \mathrm{~cm}$. The lower part of the turbidite is composed of silt or very-fine sand (broken foraminifera, quartz and other mineral fragments) and often presents fine laminations. The transition to the upper part of the 
turbidite is generally progressive, evolving to a muddy bioturbated deposit without sedimentary structures and well-preserved microfauna (only broken foraminifera). The transition to hemipelagic layers at the top of the turbidite deposit is often difficult to accurately identify because grain size and composition are not very different.

- Sandy turbidites are occasionally observed and show an erosional and sandy base composed of fine to medium sand (Fig. 7). Sandy intervals are generally laminated, normally graded, and thinner than $25 \mathrm{~cm}$. The upper part is similar to that of finegrained turbidites.

- Homogenite facies is observed in cores PSM-KS21, PSM-KS23 and PSM-KS27, once in each core, and with a thickness of 6,25 and $110 \mathrm{~cm}$ respectively. This sedimentary facies is characterized by homogeneous grey mud containing neither microfossil nor sedimentary structures (Fig. 7). It corresponds to a single deposit with a homogeneous composition. Given its unique and peculiar sedimentary character, it can be used as a stratigraphic marker (dotted grey line in fig. 6).

Each core contains between 60 and 138 turbidites. Most of them are separated by thin hemipelagic layers, but some are stacked (i.e. without hemipelagites in between).

\subsection{Chronostratigraphy and sedimentation rates}

Twenty-seven radiocarbon ages were obtained from planktonic foraminifera picked in hemipelagic intervals (Table 2, Fig. 6). The age models of the cores PSM-KS23, PSM-KS21 and PSM-KS27 are more accurate because they contain 5 or 6 radiocarbon ages in the sedimentary record of the last $9 \mathrm{kyr}$.

Based on the interpolation between radiocarbon ages, we propose a chronostratigraphic correlation of the 5 cores. Total sedimentation rates (including both turbidite and hemipelagites) over the last $9 \mathrm{kyr}$ vary from $14 \mathrm{~cm} / \mathrm{kyr}$ for PSM-KS23 to $66 \mathrm{~cm} / \mathrm{kyr}$ for 
KMDJ20, with intermediate values of $39 \mathrm{~cm} / \mathrm{kyr}$ for KMDJ18, $43 \mathrm{~cm} / \mathrm{kyr}$ for PSM-KS21, and $53 \mathrm{~cm} / \mathrm{kyr}$ for PSM-KS27. The lowest sedimentation rate is recorded in the most distal core PSM-KS23, whereas the highest rate is recorded in the most proximal core KMDJ20, in good agreement with expectations and previous results (e.g. Giresse et al., 2009).

The homogenite identified in cores PSM-KS21 ( $8.8 \mathrm{~m}$ bsf - below sea floor), PSM-KS23 ( $\sim 5 \mathrm{~m} \mathrm{bsf})$ and PSM-KS27 ( $11 \mathrm{~m} \mathrm{bsf})$ is also well correlated and its age estimated around 19-20 ka BP. The facies and the age of this homogenite are consistent with a large depositional event identified in the abyssal plain of the western Mediterranean Sea, called “megaturbidite" (Rothwell et al., 1998), which extends over several hundreds of kilometres $\left(77,000 \mathrm{~km}^{2}\right)$ and reaches a thickness of $8-10 \mathrm{~m}$ in the centre of the basin (Rothwell et al., 1998, Rothwell et al., 2000).

\subsection{Core correlation and event chronology over the last $9 \mathrm{kyr}$}

Forty individual turbidites were identified and named T1 to T40 from top to bottom. The number of turbidites varies depending on the cores. In PSM-KS23, only 13 turbidites are identified in the last $9 \mathrm{kyr}$, whereas 35 are present in PSM-KS21 (Fig. 8). In the same time interval, the number of turbidites is respectively 27, 28 and 29 in KMDJ20, KMDJ18 and PSM-KS27 (Fig. 8).

The correlation of cores PSM-KS21, KMSD18, KMSD20 and PSM-KS27 (Fig. 8) shows that the thickest and the coarsest turbidites are the same in the different cores (for example: T4, T16/T17, T23, T32/T33 or T40). Some thin and fine turbidites (silty-clay grain size and centimetre-scale thickness) are identified as single events in only one or two cores (e.g., T12, T14, T16, T19, T28 or T34), but they are stacked with the neighbouring turbidites in the other cores (Fig. 8). Except T9, T18, T21 and T25, which are each present in only a single core, all the turbidites are regionally retrieved. 
Therefore, the correlation of turbidites suggests to group single turbidites in sequences of several (up to 6 in our case) adjacent or stacked turbidites whose overall stacking pattern is identifiable from one core to another. Twelve turbidite sequences composed of one to six single turbidites are identified in the last $9 \mathrm{kyr}$ and lumped together by colour bands in Figure 8. The definition of sequences is based on both the vertical succession of turbidites in cores and the age distribution of turbidites in age models showing clusters. The correlation panel is built by the cross-analysis of turbidite sequences and age models. Age models were independently established for each core (Fig. 9). The same colour bands (figs. 7 and 8) help the identification of the turbidites in the age models (Fig. 9).

All the turbidite sequences are identified in the 5 cores except the lowermost pink sequence in PSM-KS23 (absent between 110 and $125 \mathrm{~cm}$ bsf). In PSM-KS23, turbidite sequences correspond to unique turbidites or couplets of stacked turbidites. The fit of turbidite sequences is reasonably good in age models, but it is not perfect for all single events (Fig. 9), especially for the most recent (from T2 to T8), because of uncertainties in the completeness of sediment recovery in the uppermost part of cores. The sedimentation record is probably irregular and includes lacks (erosion) that we cannot quantify and take into account, but we may assume that either erosion is comparable or it is not so relevant in the selected core sites.

\subsection{Correlation of turbidites during the last $2000 \mathrm{yr}$}

The correlation of turbidites over the last $2000 \mathrm{yr}$ is based on age models and on the analysis of turbidite successions (detailed correlation in fig. 10). After sedimentological analyses and several tests of age model, we estimate that the seafloor interface is lost in cores KMDJ18, PSM-KS23 and KMDJ20, implying the loss of the last turbidite T1. The comparison of the long core KMDJ20 and the interface core IMDJ20 at the same site (Fig. 10A and C) convincingly depicts the same record of $\mathrm{T} 4, \mathrm{~T} 3$ and $\mathrm{T} 2$, however the most recent turbidite $\mathrm{T} 1$ 
is found only at the top of IMDJ20 core. In IMDJ20, turbidites and hemipelagites are thinner, attesting for a probable stretching of the sediment by the piston in the long core KMDJ20. The turbidite T1 is also observed in cores PSM-KS21 and PSM-KS27, indicating a good preservation of the top of these two cores. The lack of turbidite T1 in PSM-KS23 can be explained by the lowest sedimentation rate $(<15 \mathrm{~cm} / \mathrm{kyr}$ including turbidites $)$, hence few centimeters of missed sediment can easily remove the most recent turbidite.

The age models of the five cores over the last $2000 \mathrm{yr}$ (Fig. 10B) show the difficulty to correlate individual events and the limits of the method of age modelling with radiocarbon ages in turbidite environments during historical times (Lowe et al., 2007; Lowe and Walker, 2015). Large time uncertainties (from 200 to 500 yr) may reach or even exceed the recurrence interval of events, leading to large temporal overlaps of events at this scale.

The location of large historical earthquakes in the age models (Fig. 10B) shows that three major earthquakes (1365 AD, 1716 AD and 2003 AD) fall in the same time interval as the four last turbidites. The 1365 earthquake was particularly strong (intensity X), destroying the city of Algiers and generating a tsunami and more than 100 aftershocks (Ambraseys and Vogt, 1988; Ayadi and Bezzeghoud, 2015). It is consistent to associate it with T4, which is the thickest turbidite in the last thousand years, reaching a thickness of $30 \mathrm{~cm}$ in PSM-KS27 (Fig. 10). Turbidite $\mathrm{T} 3$ is much thinner (less than $10 \mathrm{~cm}$ thick) and cannot be directly associated to any known earthquake. The time interval estimated for the turbidite T2 includes the $1716 \mathrm{AD}$ earthquake, and is interpreted as such.

\section{Discussion}

\subsection{Quality of core sites to record and to date paleo-events}

Obviously, active tectonic deformation acts upon seafloor morphology at the toe of the margin (Fig. 5; Domzig et al., 2006; Déverchère et al, 2005), favouring erosion and 
sedimentation by gravity flow processes. Slope instabilities (Fig. 4) evolve into turbidity currents (Dan et al., 2010) and sediments are trapped in confined basins located behind anticlines or piggy-back basins (Fig. 5). The sedimentation conditions (as sedimentation rates, distances from flow sources, local submarine topography) clearly explain different flow characteristics of turbidity currents, implying different deposits (thickness, grain size, structures...) at different sites for the same events, as observed for instance during the 2003 $\mathrm{M}_{\mathrm{w}} 6.8$ earthquake (Cattaneo et al., 2012).

In the study area, the most proximal confined basin is the "Algiers corridor"; it records high sedimentation rates as testified in seismic lines by thickening of the deposits (Fig. 5) and by the highest sedimentation rate in core KMDJ20 (66 cm/kyr over the last $9 \mathrm{kyr})$. Despite high sedimentation rates and a location at the outlet of the Algiers canyon, core KMDJ20 does not record more turbidites (27 in the last 9 kyr) than cores KMDJ18, PSM-KS21 and PSM-KS27 (Fig. 8). In the upper $5.5 \mathrm{~m}$ of core KMDJ20, turbidite facies are also dominated by finegrained turbidites, but they contain thicker muddy intervals and depict higher hemipelagic sedimentation rates (with high ratio of detrital clay and silty-clay). Consequently, the determination of the top of turbidites and the hemipelagic intervals is uncertain in this core and the possibility to get samples for radiocarbon dating with $10 \mathrm{mg}$ of foraminifera is limited, leading to a bad reliability of the age model of core KMDJ20 (Fig. 9).

Conversely, the most distal core PSM-KS23, located $60 \mathrm{~km}$ seaward from the base of the continental slope (Fig. 2), records only 13 turbidites in the last 9 kyr, with a total sedimentation rate of about $14 \mathrm{~cm} / \mathrm{kyr}$ (including turbidites and hemipelagites). Obviously, only the most powerful turbidity currents reach this area and lead to turbidite deposits at this site. The low sedimentation rate and the numerous missing turbidites do not provide a complete and accurate age model (Figs 8 and 9). 
Sedimentary records of cores KMDJ18, PSM-KS21 and PSM-KS27 are consistent. They are respectively located at about 10, 20 and $30 \mathrm{~km}$ away from the base of slope, and contain 29 , 35 and 28 turbidites in the last 9 kyr (Fig. 8). The total sedimentation rates (including turbidites) range from 39 to $53 \mathrm{~cm} / \mathrm{kyr}$. Core KMDJ18 is located at the top of the Algiers ridge, whereas cores PSM-KS21 and PSM-KS27 are located in the deep and open basin in front of the distal morphological high (related to deformation), and on the paths of potential turbidity currents (Cattaneo et al., 2012) as demonstrated by the 2003 cable breaks (Fig. 3). Sedimentary facies and depositional sequences show more similarities in PSM-KS21 and PSM-KS27 despite a distance of $65 \mathrm{~km}$ between these two cores. The record of cores PSMKS21 and PSM-KS27 allows a good visual discrimination of turbidites and hemipelagites and six radiocarbon ages obtained in both cores provide well-constrained age models.

Comparing the turbidite record of all the cores, the choice of the best location of core sites for turbidite paleoseismology appears as a compromise between: (1) sedimentation rate (vertical resolution of the age models) and quality of the hemipelagic sediment (true pelagic content for the facies determination and foraminifera content for dating), (2) distance from the sediment sources and more specifically location along the pathways of turbidity currents, in order to record the maximum number of significant events. In the central segment of the Algerian margin, the best sites are located 20 to $30 \mathrm{~km}$ away from the base of the continental slope, in the deep basin, seaward from the structural highs, and directly along the potential pathways of the turbidity currents (location of cores PSM-KS21 and PSM-KS27).

\subsection{Seismic trigger of turbidity currents}

Several criteria have been proposed to determine the seismic origin of turbidites. They include the type of canyon morphology (Piper and Normark, 2009), the large extent of single turbidites (Talling et al., 2007), sedimentological criteria such as the variable provenance of 
sediments (multi-sources) and multi-pulse turbidite deposits (Nakajima and Kanai, 2000; Shiki et al., 2000; Gutierrez-Pastor et al., 2013; Van Daele et al., 2014). Determining the seismic origin of a turbidite is not straightforward and several criteria need to be taken into account (Goldfinger et al., 2003, 2014; Talling, 2014). Overall, the most robust criterion is the synchronicity of multi-source turbidite deposition over a wide spatial extent (Goldfinger, 2014; Talling, 2014).

In the Algiers area, the first criteria excluding climatic triggering (especially floods, hyperpycnal flows) over the last $9 \mathrm{kyr}$ is the presence of the shelf during the Holocene. Canyon heads are clearly disconnected from the river mouths and fluvial sediment discharges are trapped on the Algerian shelf. Moreover, the seismic trigger of turbidity currents is based on the following : (1) the $2003 \mathrm{M}_{\mathrm{w}} 6.8$ earthquake and associated cable breaks (Cattaneo et al., 2012), (2) the consistency between the sedimentary record and the $1000 \mathrm{yr}$ long historical record of the greatest magnitude earthquakes, (3) the similar number of turbidites and depositional sequences in four cores with potential different sources of turbidity currents.

\section{- Correlation with the $2003 M_{w} 6.8$ Boumerdès earthquake}

In the last century, only two significant events with multiple breaks of submarine communication cables occurred off Algeria: $\sim 200 \mathrm{~km}$ to the west of our study area, after the Orléansville $M_{\mathrm{s}} 6.7$ earthquake in 1954 (Heezen and Ewing, 1955), and in the Algiers area after the Boumerdès $M_{w} 6.8$ earthquake in 2003 (Cattaneo et al., 2012). Turbidity currents capable of breaking submarine cables are nowadays widely used to assess and discuss competing triggering mechanisms such as seismic or weather events (e.g. Pope et al., Gavey et al, this volume). Off Algiers, submarine cable breaks following the 2003 earthquake (Fig. 3) have evidenced a series of synchronously triggered turbidity currents along distinct turbiditic systems over a distance of $150 \mathrm{~km}$ and as far as $70 \mathrm{~km}$ away from the coastline (Cattaneo at al., 2012). The main source of the submarine gravity flows is near the Algiers 
canyon, especially for core sites KMDJ20 and PSM-KS27. Cores KMDJ18, PSM-KS23 and mostly PSM-KS21 were probably fed by other sources on the continental slope, further to the west. Therefore we postulate that correlated turbidites across 4 or 5 cores can be associated to earthquakes with comparable characteristics (i.e., similar distance and magnitude) to the 2003 event.

\section{- Consistency between turbidites and historical earthquakes}

A second argument to associate turbidites and large earthquakes in the Algiers area is the good consistency between the number of large historical earthquakes and turbidites in the last thousand years (Fig. 10B). Before 1900 AD, knowledge of historical earthquakes is based on human perception of shaking, with description of earthquake effects and damages and interpretation of intensity values reported (Ayadi and Bezzeghoud, 2015). In our study, we only consider historical earthquakes with significant effects on Algiers and with estimated intensities from IX to XI (Ayadi and Bezzeghoud, 2015 and references therein). Three earthquakes were reported with a significant impact on Algiers city: Algiers 1365 AD, Algiers 1716 AD, and Boumerdès 2003 AD (location in Fig. 1). Two additional earthquakes can probably be taken into account. They affected an area further to the south, near Blida city: i.e. Blida $1825 \mathrm{AD}$ and Mouzaïa 1867 AD. These two events probably induced less submarine gravitational instabilities because of their greater distance from the continental slope (estimated location at more than $30 \mathrm{~km}$ from the coast).

Moreover, the ancient historical archives between $1365 \mathrm{AD}$ and $1716 \mathrm{AD}$ might be incomplete, especially for coastal events without considerable damage in the largest cities. It cannot be excluded that turbidity currents were generated by an earthquake during this time interval, and in that case such an event would have been less damaging than the 1365 AD earthquake. Thus, we can consider at least 3 events (and possibly 4 or 5) able to generate large turbidity currents since 1365 AD. 
Turbidites T1, T2 and T4 can be associated with the 1365 AD, the 1716 AD and the 2003 AD earthquakes, respectively (Fig. 10). Conversely, the two earthquakes in the Blida area (1867 $\mathrm{AD}$ and $1825 \mathrm{AD})$ are apparently not recorded as turbidites at the core sites. The relatively high distance of the seismic epicentres (ca. $30 \mathrm{~km}$ from the coastline) and/or their time occurrences close to the 1716 event (i.e. after less than one century and half, potentially too short for a significant sediment supply, see e.g. Goldfinger et al., this volume) could explain the absence of turbidity currents trigger. However, we cannot rule out the hypothesis that one of these earthquakes has triggered the T2 turbidite (Fig. 10) instead of the 1716 event. The turbidite T3 is a thin turbidite (stacked with T4 in PSM-KS23), which does not correspond to any known historical earthquake. It occurred between 1365 AD and $1716 \mathrm{AD}$ and could correspond to another coastal earthquake with a low or moderate effect on Algiers city (not mentioned in historical archives).

- Synchronicity of turbidites between independent cores

In this study, the good correlation of individual turbidite deposits is also a strong evidence for the trigger of large multi-source turbidity currents. The number of turbidites and their age are highly consistent in the cores despite the distance from the coast and the different sedimentary settings of the core locations (for example 27 and 28 turbidites for cores KMDJ20 at the base of the slope and PSM-KS27 in the basin, see Figure 2). Except only for four isolated deposits 36 turbidites retrieved at the base of the continental slope in the last $9 \mathrm{kyr}$ are synchronous and with a large regional extent; they can be considered as a record of large paleoearthquakes.

\subsection{Improvement of temporal accuracy}

Considering that 36 turbidites represent the signatures of large earthquakes $(\mathrm{M} \sim 6.5$ and more), the cores PSM-KS21 and PSM-KS27 show the most complete sedimentary records of 
these events and can provide a reliable first-order paleoseismological chronology for the Algiers area during the last $9 \mathrm{kyr}$.

The age estimations for each turbidite (OxCal models), provide a relatively low accuracy for a paleoseismological approach (error bars up to $300 \mathrm{yr}$ ). Although the first-order turbidite correlation was based on turbidite age overlaps between cores, the correlation appears even more robust using turbidite successions (with sedimentological analysis and correlations). To improve the temporal accuracy, we constructed synthetic age models for cores PSM-KS21 and PSM-KS27 in order to show the most complete paleoseismological record. Key radiocarbon ages of neighbouring cores are projected and new age models were computed for the two cores, including respectively 11 and 10 dates (Fig. 11). The error bars on the ages of the turbidites are reduced and the correlation between the two cores is optimised.

\subsection{Earthquake recurrence intervals and cycling}

Recurrence intervals of turbidites are calculated based on the mean ages of the events (Fig. 12B). They vary theoretically from $\sim 50 \mathrm{yr}$ to $\sim 900 \mathrm{yr}$ (Fig. 12B). Most of them are shorter than $450 \mathrm{yr}$ (dashed line in Fig. 12B) with a mean value of $\sim 250 \mathrm{yr}$. However, three intervals exceed $450 \mathrm{yr}$ and can as such be considered as seismic quiescences: 7-6.2 ka BP, 5.4-4 ka $\mathrm{BP}$, and -the shortest of the three intervals- 1.5-1 ka BP (events above dashed line, Fig. 12B). The occurrence of events seems to follow 2000 to $3000 \mathrm{yr}$ long cycles, with event clusters (recurrence intervals between 50 to $400 \mathrm{yr}$ ) separated by periods without events longer than 450 yr. Such cycles could result from variations of sediment supply linked to Holocene eustatic or climatic pulses or from changes in seismic activity. Actually, there are growing evidences that stress changes of external origin could modulate the tectonic stress field (Calais et al., in press, and references therein), resulting into temporal clustering and 
quiescence of large earthquakes, as evidenced by Ratzov et al. (2015) on the western part of the Algerian margin.

Our results provide for the first time a chronology of the largest paleo-earthquakes of the margin off the highly populated Algiers, but the estimation of the magnitude of the earthquakes responsible for slope failures remains difficult. In this area, the only earthquake that triggered significant turbidity currents with a well-determined magnitude and epicentre is the $2003 \mathrm{M}_{\mathrm{w}} 6.8$ Boumerdès event. Obviously, a single event is not enough to calibrate the sensitivity of the continental margin to regional earthquakes (or magnitude threshold), and magnitude threshold for causing mass flows depends strongly on several preconditioning factors and seismicity patterns, precluding a specific value at global scale (Pope et al., this volume). However, several studies have pointed out that the magnitude threshold allowing a sufficient peak ground acceleration to trigger turbidity currents and slope failures is probably lower than 6.8 for close earthquakes sources, and potentially around 6.5 at distances up to 50 km (e.g. Keefer, 1984; Zàruba and Mencl, 2014; Ratzov et al., 2015; Pope et al., this volume).

\subsection{Comparison with the Kramis area in the western Algerian margin}

The analysis of turbidites triggered by earthquakes in the western Algerian margin (Kramis area, Ratzov et al., 2015) has led to a paleoseismological record of 13 large events in the last $8 \mathrm{kyr}$. The time distribution of these events is bimodal, following supercycles with clusters of 3 to 6 events with recurrence intervals of 300-600 yr separated by quiescence periods of $\sim 1.6$ kyr without any major event. Although this study and the results by Ratzov et al. (2015) are based on a similar dataset and are conducted along the same margin (Fig. 1), with similar characteristics in terms of sediment input and slope morphology, the sedimentary record of events is strikingly different. The number and frequency of events are 13 events in 8 kyr off Kramis and 36 events in 9 kyr off Algiers, i.e. 2.5 higher in the Algiers area. Mean recurrence 
intervals of events are shorter off Algiers (250 yr, compared to $660 \mathrm{yr}$ off Kramis) and the quiescence periods (defined here arbitrarily as periods longer than $450 \mathrm{yr}$ ) are shorter too (800-1400 yr, compared to ca. $1600 \mathrm{yr}$ off Kramis). The comparison of the time intervals of quiescence and cluster periods between the two margin segments shows that they are not synchronous but rather out of phase (Figs. 12B and C). This is the first evidence for a shift of large earthquake activity in two adjacent tectonic segments of the Algerian margin.

Possible explanations for the difference in the number of events and recurrence intervals could be: (1) a higher seismic activity of the Algiers area than in Kramis area, and/or (2) a higher sensitivity of the Algiers area to continental slope instabilities for lower magnitude earthquakes (linked to a quicker sediment reload and shorter distances of earthquake epicentres to the continental slope). In both Algiers and Kramis areas, a similar order of shortening, fault length, seismic moment, and geodetic strain rates are reported (Serpelloni et al., 2007). Historical earthquakes and instrumental seismicity do not evidence strong contrasts in the seismic activity between both margin segments (Ambraseys and Vogt, 1988; Hamdache et al., 2010; Ayadi and Bezzeghoud, 2015). The more probable hypothesis is therefore the potential triggering of large turbidity currents by earthquakes of lower magnitude in the Algiers area. Indeed, the Kramis area is characterized by active faults located far inland (typically, 50-100 km, see e.g. Beldjoudi et al., 2011), while a significant part of the active deformation in the Algiers area occurs near the coastline and in the submarine domain (Déverchère et al., 2005; Domzig et al., 206; Yelles et al., 2009; Strzerzynski et al., 2010; see also the location of tectonic ridges and $2003 \mathrm{M}_{\mathrm{w}} 6.8$ earthquake in Figures 4 to 5), i.e. very close to the sources of the turbidity currents.

Given the peak ground acceleration (PGA) versus magnitude versus distance predictions performed by Ratzov et al. (2015), the minimum magnitude of nearby earthquakes triggering slope failures (and therefore turbidity currents) should be 6.0 (or lower) in the Algiers area, 
and 6.5 in the Kramis area. Obviously, it appears that at the scale of the Algerian margin, a shorter distance of epicenters to zones of slope failures of only a few tens of kilometers lowers the magnitude threshold down to 5.5-6 and could explain the discrepancy of recurrence intervals in the turbidite record between these two margin segments of Algeria (Kramis and Algiers, respectively; Fig. 12B). This interpretation implies that the amount of submarine soft sediments available on the slope for triggering turbidity currents is accumulated on time intervals probably much shorter than at least the earthquake mean recurrence times of $250 \mathrm{yr}$ found in the Algiers area.

The core PSM-KS23 (Fig. 2 and 8) in the deep basin of Algiers area shows a similar mean frequency of turbidites (13 in $9 \mathrm{kyr}$ ) as offshore Kramis (13 in $8 \mathrm{kyr}$ ). Given the $60 \mathrm{~km}$ distance from the base of the slope compared to other core sites, only the most powerful turbidity currents reach this core site, most likely triggered by the biggest earthquakes. Therefore, we believe that this sedimentary record is probably representative of the largest earthquakes (possibly magnitude $\sim 7$ or more), as expected in the Kramis region too (Ratzov et al., 2015). This result probably means that the return periods of large $\left(M_{w} \geq 6.5\right)$ earthquakes are similar for both margin segments: indeed, periods of times separating the so-called quiescence periods (i.e., the duration of a supercycle) are similar $(2500-3000 \mathrm{yr})$ and both regions depict clusters of 3-6 events with recurrence intervals of ca. 200-600 yr (Ratzov et al., 2015) in between the quiescence periods (Fig. 12B and C). Durations of seismic quiescences are apparently different but this may result from the different magnitude thresholds discussed above. However, it remains unclear whether earthquake supercycle periods are exactly superimposed and whether fault synchronicity in the Algiers region is indeed occurring.

\section{Conclusions}


This study proposes a paleoseismological approach of the central segment of the Algerian margin (Algiers area) during the last $9 \mathrm{kyr}$, based on a sedimentological and stratigraphic analysis of 5 cores located in the deep basin at the base of the continental slope. Forty turbidites are identified, dated and correlated over an area of $65 \mathrm{~km}$ along the Algerian coastline. Turbidite correlations based on sedimentary facies and age models (based on radiocarbon ages) allow an accurate determination of individual events despite the diversity of coring sites, which include base of slope, morphological highs, confined and open basins.

The turbidite characteristics in terms of sedimentological facies, number and spatial extent, and the comparison of these characteristics with the 2003 event (earthquake and turbidity currents observed by cable breaks) suggest a good potential to use the turbidite record as a paleoseismological record. This hypothesis is also confirmed by the good correspondence between the largest historical earthquakes in the Algiers area during the last millennium (2003, 1716 and 1365 AD) and the age modelling of the four last events. The large earthquake of $1365 \mathrm{AD}$ that destroyed the city of Algiers and generated a tsunami, is clearly identified in the sedimentary record as a major turbiditic deposit.

Among the 40 identified turbidites, 36 are identified as potential individual turbidite deposits corresponding to seismic events during the last $9 \mathrm{kyr}$, with magnitudes possibly higher than 5.5-6.0. The average recurrence interval of these earthquakes is $250 \mathrm{yr}$, but with a high variability (theoretical times ranging from 50 to $900 \mathrm{yr}$ ). By arbitrarily defining recurrence intervals longer than $450 \mathrm{yr}$ as quiescence periods, three quiescence periods are observed in the last 9 kyr (7-6.2 ka BP, 5.4-4 ka BP, and 1.5-1 ka BP), suggesting a bimodal cyclicity in the seismic activity.

Although the sedimentary and paleoseismological records differ from the results by Ratzov et al. (2015) on the same margin (western segment - Kramis area), the observation of earthquake cycling is compatible in both studies. The different number of events and 
recurrence intervals (13 events in $8 \mathrm{kyr}$ in the Kramis area against 36 events in $9 \mathrm{kyr}$ in the Algiers area) could be explained by the vicinity of seismogenic faults below the continental slope in the Algiers area, whereas active faults in the Kramis area are located further inland (several tens of kilometers).

\section{Acknowledgments}

The authors thank captains and crews of cruises MARADJA 2003 and MARADJA2/SAMRA 2005 (R/V Le Suroît) and PRISME 2007 (R/V L'Atalante). This research was funded by the French-Algerian PHC Tassili Partnership (Project 12MDU877 Simoseda) and by the CNRSINSU Program ALEAS. The project also benefits from the support of the LabexMER (ANR10-LABX-19-01, IUEM, Brest) and FP7-ENV2013 6.4-3 ASTARTE. CNRS-INSU Artemis Program provided most of ${ }^{14} \mathrm{C}$ dates. We dedicate this work to the memory of Bruno Savoye who launched this project and was an inspiring leader for the understanding of turbidite processes.

\section{References}

Adams, J., 1990. Paleoseismicity of the Cascadia Subduction Zone: Evidence from turbidites off the Oregon-Washington Margin. Tectonics 9, 569-583, doi:10.1029/TC009i004p00569.

Alasset, P.-J., Hébert, H., Maouche, S., Calbini, V., Meghraoui, M., 2006. The tsunami induced by the 2003 Zemmouri earthquake (MW = 6.9, Algeria): modelling and results. Geophys. J. Int. 166, 213-226.

Ambraseys, N., Vogt, J., 1988. Material for the investigation of the seismicity of the region of Algiers. Eur. Earthquake Engin. 3, 16-29.

Ayadi, A., Dorbath, C., Ousadou, F., Maouche, S., Chikh, M., Bounif, M. A., Meghraoui, M., 2008. Zemmouri earthquake rupture zone (Mw 6.8, Algeria): Aftershocks sequence relocation and 3D velocity model. J. Geophys. Res. 113, B09301, doi:10.1029/2007JB005257.

Ayadi, A., Bezzeghoud, M., 2015. Seismicity of Algeria from 1365 to 2013: Maximum Observed Intensity Map (MOI $\left.{ }_{2014}\right)$. Seismol. Res. Lett. 86, 1-9, doi:10.1785/0220140075.

Babonneau, N., Cattaneo, A., Savoye, B., Barjavel, G., Déverchère, J., Yelles, K., 2012. The Kramis deep-sea fan off western Algeria: Role of sediment waves in turbiditic levee growth. In Prather, B. E., Deptuck, M.E., Mohrig D., Van Hoorn B., Wynn, R. B. (eds), Application of the principles of seismic geomorphology to continental-slope and base-of-slope systems: Case studies from seafloor and near-seafloor analogues, SEPM Special Publication 99, ISBN: 978-156576-304-3, DOI : 10.2110/pec.12.99. 
Beldjoudi, H., Delouis, B., Heddar, A., Nouar, O.B., Yelles-Chaouche, A., 2011. The Tadjena earthquake $(\mathrm{Mw}=5.0)$ of December 16, 2006 in the Cheliff region (northern Algeria): Waveform modelling, regional stresses, and relation with the Boukadir fault. Pure and Applied Geophysics 169, 677-691, doi:10.1007 /s00024-011-0337-8.

Bernhardt, A., Melnick, D., Hebbeln, D., Lückge, A., Strecker, M.R., 2015. Turbidite paleoseismology along the active continental margin of Chile - Feasible or not? Quaternary Science Reviews 120, 71-92.

Bounif, A., Dorbath, C., Ayadi, A., Meghraoui, M., Beldjoudi, H., Laouami, N., Frogneux, M., Slimani, A., Alasset, P., Kher- roubi, A., Ousadou, F., Chikh, M., Harbi, A., Larbes, S., Maouche, S., 2004. The 21 May 2003 Zemmouri (Algeria) earthquake Mw 6.8: Relocation and aftershock sequence analysis. Geophys. Res. Lett. 31, L19606, doi:10.1029/2004GL020586.

Bronk Ramsey, C., 2008, Depositional models for chronological records. Quaternary Science Reviews $27,42-60$.

Calais, E., Camelbeeck, T. Stein, S. M. Liu, M.,Craig, T.J., 2016. A New Paradigm for Large Earthquakes in Stable continental interiors, Geophys. Res. Lett., doi:10.1002/2016GL070815.Cattaneo, A. Babonneau, N., Dan, G., Déverchère, J., Domzig, A., Gaullier, V., Lepillier, B., Mercier de Lépinay, B., Nouguès, A., Strzerzynski, P., Sultan, N., Yelles, K., 2010. Submarine slides along the Algerian margin: a review of their occurrence and potential link with tectonic structures. In: D. Mosher, DC., Shipp, C., Moscardelli, L., Chaytor, J., Baxter, C., Lee, H., and Urgeles, R. (Eds.), Submarine Mass Movements and Their Consequences - Advances in Natural and Technological Hazards Research 28, 507-518.

Cattaneo, A., Babonneau, N., Ratzov, G., Dan-Unterseh, G., Yelles, K., Bracène, R., Mercier de Lepinay, B., Boudiaf, A., Déverchère, J., 2012. Searching for the seafloor signature of the 21 May 2003 Boumerdès earthquake offshore central Algeria. Natural Hazards and Earth System Sciences 12, 2159-2172.

Dan, G., Sultan, N., Savoye, B., Déverchère, J., Yelles, K., 2009. Quantifying the role of sandy-silty sediments in generating slope failures during seismic shaking: Example from the Algerian margin. Int. J. Earth Sci. 98, 769-789, doi:10.1007/s00531-008- 0373-5.

Dan, G., Sultan, N., Cattaneo, A., Déverchère, J., Yelles, K., 2010. Mass-transport deposits on the Algerian Margin (Algiers Area): Morphology, Lithology and Sedimentary Processes.Iin: Submarine Mass Movements and Their Consequences, edited by: Mosher, D., Moscardelli, L., Baxter, C. D. P., Urgeles, R., Shipp, R. C., Chaytor, J. D., and Lee, H. J., Adv. Nat. Technol. Haz., Springer 28, 527-539.

Dan-Unterseh, G., Savoye, B., Gaullier, V., Cattaneo, A., Déverchère, J., Yelles, K., and MARADJA 2003 Team, 2011. Algerian margin sedimentation patterns (Algiers area, south-western Mediterranean). In: Mass-Transport Deposits in Deepwater Settings, edited by: Shipp, R. C., Weimer, P., and Posamentier, H. W., AAPG-SEPM Special Volume 96, 69-84.

Delouis, B., Vallée, M., Meghraoui, M., Calais, E., Maouche, S., Lammali, K., Mahsas, A., Briole, P., Benhamouda, F., Yelles, K., 2004. Slip distribution of the 2003 Boumerdes-Zemmouri earthquake, Algeria, from teleseismic, GPS, and coastal uplift data. Geophys. Res. Lett. 31, L18607, doi:10.1029/2004GL020687.

Déverchère J., Yelles K., Domzig A., Mercier de Lépinay B., Bouillin J.-P., Gaullier V., Bracène R., Calais E., Savoye B., Kherroubi A., Le Roy P., Pauc H., Dan G., 2005. Active thrust faulting offshore Boumerdes, Algeria, and its relations to the $2003 \mathrm{Mw} 6.9$ earthquake. Geophys. Res. Lett. 32, L04311. Doi:10.1029/2004GL021646.

Déverchère, J., Mercier de Lépinay, B., Cattaneo, A., Strzerzynski, P., Calais, E., Domzig, A., Bracène, R., 2010. Comment on "Zemmouri earthquake rupture zone (Mw 6.8, Algeria): Aftershocks sequence relocation and 3D velocity model" by Ayadi et al. J. Geophys. Res. 115, B04320, doi:10.1029/2008JB006190.

Domzig, A., Le Roy, C., Yelles, K., Déverchère, J., Bouillin, J-P., Bracène, R., Mercier de Lépinay, B., Le Roy, P., Calais, E., Kherroubi, A., Gaullier, V., Savoye, B., Pauc, H., 2006. Searching for 
the Africa-Eurasia Miocene boundary offshore Western Algeria (MARADJA'03 Cruise). C.R. Geoscience 338, 80-91, doi:10.1016/ j.crte.2005.11.009.

El-Robrini, M., Gennesseaux, M., Mauffret, A., 1985. Consequences of the El-Asnam earthquakes: turbidity currents and slumps on the Algerian margin (western Mediterranean). Geo-Marine letters 5, 171-176.

Gavey, R., Carter, L., Liu, J.T., Talling, P.J., Hsu, R., Pope, E., Evans, G., 2016. Frequent sediment density flows during 2006 to 2015, triggered by competing seismic and weather events: Observations from subsea cable breaks off southern Taiwan. Mar. Geol., this volume.

Giresse, P., Pauc, H., Déverchère, J., and the MARADJA Shipboard party, 2009. Sedimentary processes and origin of sediment gravity-flow deposits on the western Algerian margin during late Pleistocene and Holocene. Mar. Petrol. Geol, 26, 659-674, doi:10.1016/j.marpetgeo.2008.03.011.

Goldfinger, C., Nelson, C.H., Johnson, J.E., and Party, S.S., 2003. Holocene earthquake records from the Cascadia subduction zone and northern San Andreas Fault based on precise dating of offshore turbidites. Annual Review of Earth and Planetary Sciences 31, 555-577, doi: 10.1146/annurev.earth.31.100901.141246.

Goldfinger, C., Morey, A.E., Nelson, C.H., Gutierrez-Pastor, J., Johnson, J., Karabanov, E., Chaytor, J., Eriksson, A., 2007. Rupture lengths and temporal history of significant earthquakes on the offshore and north coast segments of the Northern San Andreas Fault based on turbidite stratigraphy. Earth Planet. Sci. Lett. 254, 9-27.

Goldfinger, C., Ikeda, Y., Yeats, R.S., and Ren, J., 2013. Superquakes and supercycles. Seismological Research Letters 84, 24-32, doi: 10.1785/0220110135.

Golfinger, C., Galer, S., Beeson, J., Hamilton, T., Black, B., Romsos, C., Patton, J., Nelson, C.H., Hausmann, R., Morey, A., 2016. The importance of site selection, sediment supply, and hydrodynamics: A case study of submarine paleoseismology on the northern Cascadia margin, Washington USA. Mar. Geol., this volume.

Goldfinger, C., Patton, J.R., Daele, M. Van, Moernaut, J., Nelson, C.H., Batist, M. de, Morey, A.E., 2014. Can turbidites be used to reconstruct a paleoearthquake record for the central Sumatran margin? Comment. Geology 42, e344.

Gorsline, D., Diego, T. De, Nava-Sanchez, E., 2000. Seismically triggered turbidites in small margin basins: Alfonso Basin, western Gulf of California and Santa Monica Basin, California borderland. Sediment. Geol. 135, 21e35.

Gràcia, E., Vizcaino, A., Escutia, C., Asioli, A., Rodés, A., Pallàs, R., Garcia Orellana, J., Lebreiro, S., and Goldfinger, C., 2010, Holocene earthquake record offshore Portugal (SW Iberia): Testing turbidite paleoseismology in a slow-convergence margin. Quaternary Science Reviews 29, 1156-1172, doi:10.1016/j.quascirev.2010.01.010.

Gràcia, E., Lamarche, G., Nelson, H., and Pantosti, D., 2013, Preface: Marine and Lake Paleoseismology. Nat. Hazards Earth Syst. Sci. 13, 3469-3478, doi:10.5194/nhess-13-34692013.

Gutiérrez-Pastor, J., Nelson, C.H., Goldfinger, C., Escutia, C., 2013. Sedimentology of seismoturbidites off the Cascadia and northern California active tectonic continental margins, northwest Pacific Ocean. Mar. Geol. 336, 99-119.

Hamdache, M., Pelaez, J. A., Talbi, A., and Casado, C. L., 2010 A Unified Catalog of Main Earthquakes for Northern Algeria from A.D. 856 to 2008. Seismol. Res. Lett. 81, 732-739, doi:10.1785/gssrl.81.5.732.

Harbi, A., Maouche, S., Ousadou, F., Rouchiche, Y., Yelles-Chaouche, A., Merahi, M., Heddar, A., Nouar, O., Kherroubi, A., Beldjoudi, H., Ayadi, A., and Benouar, D., 2007. Macroseismic Study of the Zemmouri Earthquake of 21 May 2003 (Mw 6.8, Alegeria). Earthquake Spectra 23, 315-332.

Heezen, B.C., and Ewing, M., 1955, Orléansville earthquake and turbidity currents. Bulletin of the American Association of Petroleum Geologists 39(12), 2505-2514. 
Keefer, D.K., 1984. Landslides caused by earthquakes. Geol. Soc. Am. Bull., 95, 406 - 421.

Kherroubi, A., Déverchère, J., Yelles, A., Mercier de Lépinay, B., Domzig, A., Cattaneo, A., Bracène, R., Gaullier, V., Graindorge, D., 2009. Recent and active deformation pattern off the easternmost Algerian margin, Western Mediterranean Sea: New evidence for contractional tectonic reactivation. Mar. Geol. 261, 17-32.

Lowe, J.J., Blockley, S., Trincardi, F., Asioli, A., Cattaneo, A., Matthews, I.P., Pollard, A.M., Wulf, S., 2007. Age modelling of late Quaternary marine sequences in the Adriatic: Towards improved precision and accuracy using volcanic event stratigraphy. Continental Shelf Research 27, 560-582.

Lowe, J., Walker, M., 2015. Measuring Quaternary time: A 50-year perspective. Journal of Quaternary Science 30(2), 104-113.

Mahsas, A., Lammali, K., Yelles, K., Calais, E., Freed, A. M., Briole, P., 2008. Shallow afterslip following the 2003 May 21, Mw = 6.9 Boumerdes earthquake, Algeria. Geophys. J. Int. 172, $155-166$.

McCalpin, J.M., 2009. Paleoseismology. International Geophysics Series, vol. 95. Academic Press, ISBN- 9780123735768, $647 \mathrm{p}$.

Meghraoui, M., Maouche, S., Chemaa, B., Cakyr, Z., Aoudia, A., Harbi, A., Alasset, P., Ayadi, A., Bouhadad, Y., Ben- hamouda, F., 2004. Coastal uplift and thrust faulting associated with the $\mathrm{Mw}=6.8$ Zemmouri (Algeria) earthquake of 21 May, 2003. Geophys. Res. Lett. 31, L19605, doi:10.1029/2004GL020466.

Migeon, S., Savoye, B., Zanella, E., Mulder, T., Faugères, J.C., Weber, O., 2001. Detailed seismicreflection and sedimentary study of turbidite sediment waves on the Var Sedimentary Ridge (SE France): significance for sediment transport and deposition and for the mechanisms of sediment-wave construction. Marine Petrol. Geol., 18, 179-208.

Moernaut, J., De Batist, M., Heirman, K., Van Daele, M., Pino, M., Brümmer, R., Urrutia, R., 2009. Fuidization of buried mass-wasting deposits in lake sediments and its relevance for paleoseismology: results from a reflection seismic study of lakes Villarica and Calafquén (South-Central Chile). Sedimentary Geology, 231(3/4):121-135.

Nakajima, T., Kanai, Y., 2000. Sedimentary features of seismoturbidites triggered by the 1983 and older historical earthquakes in the eastern margin of the Japan Sea. Sediment. Geol. 135, 1e19.

Nouguès, A., Sultan, N., Cattaneo, A., Dan, G., Yelles, K., 2010. Detailed Analysis of a Submarine Landslide (SAR-27) in the Deep Basin Offshore Algiers (Western Mediterranean). In: Submarine Mass Movements and Their Consequences, edited by: Mosher, D., Moscardelli, L., Baxter, C. D. P., Urgeles, R., Shipp, R. C., Chaytor, J. D., and Lee, H. J., Adv. Nat. Technol. Haz., Springer, 28, 541-552.

Palano, M., Gonzàlez, P.J., Fernàndez, J., 2015. The diffuse plate boundary of Nubia and Iberia in the Western Mediterranean: Crustal deformation evidence for viscous coupling and fragmented lithosphere. Earth Planet. Sci. Lett., 430, 439-447, doi:10.1016/j.epsl.2015.08.040.

Piper, D.J.W., Normark, W.R., 2009. Processes that initiate turbidity currents and their influence on turbidites: a marine geology perspective. J. Sediment. Res. 79, 347-362.

Polonia, A., Panieri, G., Gasperini, L., Gasparotto, G., Bellucci, L.G., Torelli, L., 2013. Turbidite paleoseismology in the Calabrian arc subduction complex (Ionian sea). Geochem. Geophys. Geosyst. 14, 112-140, doi:10.1029/2012GC004402.

Pope, E., Talling, P.J., Carter, L., 2016. Which earthquakes trigger damaging submarine mass movements: Insights from a global record of submarine cable breaks? Mar. Geol., this volume.

Pouderoux, H., Proust, J.-N., Lamarche, G., 2014, Submarine paleoseismology of the north- ern Hikurangi subduction margin of New Zea- land as deduced from turbidite record since $16 \mathrm{ka}$. Quaternary Science Reviews 84, 116- 131, doi:10.1016/j.quascirev.2013.11.015.

Ratzov G., Cattaneo A., Babonneau N., Déverchère J., Yelles K., Bracene R., Courboulex F., 2015, Holocene turbidites record earthquake supercycles at slow rate plate boundary. Geology 43, 331-334, doi:10.1130/G36170.1. 
Reimer, P. J., Bard, E., Bayliss, A., Beck, J. W., Blackwell, P. G., Bronk Ramsey, C., Grootes, P. M., Guilderson, T. P., Haflidason, H., Hajdas, I., Hatt, C., Heaton, T. J., Hoffmann, D. L., Hogg, A. G., Hughen, K. A., Kaiser, K. F., Kromer, B., Manning, S. W., Niu, M., Reimer, R. W., Richards, D. A., Scott, E. M., Southon, J. R., Staff, R. A., Turney, C. S. M., van der Plicht, J., 2013, IntCal13 and Marine13 Radiocarbon Age Calibration Curves 0-50,000 Years cal BP. Radiocarbon 55(4).

Rothwell, R.G., Thomson, J., Kähler, G., 1998, Low-sea-level emplacement of a very large Late Pliocene 'Megaturbidite' in the western Mediterranean Sea. Nature 392, 377-380.

Rothwell, R.G., Reeder, M.S., Anastasakis, G., Stow, D.A.W., Thomson, J., Kähler, G., 2000, Low sea-level stand emplacement of megaturbidites in the western and eastern Mediterranean Sea. Sedimentary Geology 135, 75-88.

Semmane, F., Campillo, M., Cotton, F., 2005. Fault location and source process of the Boumerdes, Algeria, earthquake inferred from geodetic and strong motion data. Geophys. Res. Lett. 32, L01305, doi:10.1029/2004GL021268.

Serpelloni, E., Vannucci, G., Pondrelli, S., Argnani, A., Casula, C., Anzidei, M., Baldi, P., Gasperini, P., 2007. Kinematics of the Western Africa-Eurasia plate boundary from focal mechanisms and GPS data. Geophys. J. Int. 169, 1180-1200, doi:10.1111/j.1365-246X.2007.03367.x.

Shiki, T., Kumon, F., Inouchi, Y., Kontani, Y., Sakamoto, T., Tateishi, M., Matsubara, H., Fukuyama, K., 2000. Sedimentary features of the seismo-turbidites, Lake Biwa, Japan. Sedimentary Geology 135, 37-50.

Sims, J., 1973. Earthquake-induced structures in sediments of Van Norman Lake, San Fernando, California. Science 182, 161-163.

Sims, J., 1975. Determining earthquake recurrence intervals from deformational structures in young lacustrine sediments. Tectonophysics 29, 141-152.

Stich, D., Serpelloni, E., de Lis Mancilla, F., Morales, J., 2006, Kinematics of the Iberia- Maghreb plate contact from seismic moment tensors and GPS observations. Tectonophysics 426, 295317, doi:10.1016/j.tecto.2006.08.004.

Strzerzynski, P., Déverchère, J., Cattaneo, A., Domzig, A., Yelles, K., Mercier de Lépinay, B., Babonneau, N. Boudiaf, A. 2010. Tectonic inheritance and Pliocene-Pleistocene inversion of the Algerian margin around Algiers: Insights from multibeam and seismic reflection data. Tectonics 29, TC2008, 1-22.

Talling, P.J., Amy, L.A., Wynn, R.B., 2007. New insight into the evolution of large- volume turbidity currents: comparison of turbidite shape and previous modelling results. Sedimentology 54, $737 \mathrm{e} 769$.

Talling, P.J., 2014. On the triggers, resulting flow types and frequencies of sub-aqueous sediment density flows in different settings. Marine Geology 352, 155e182.

ten Brink, U.S., Lee H.J., Geist E.L., Twichell, D., 2009. Assessment of tsunami hazard to the U.S. East Coast using relationships between submarine landslides and earthquakes. Marine Geology 264, 65-73.

Van Daele, M., Cnudde, V., Duyck, P., Pino, M., Urrutia, R., De Batist, M., 2014. Multidirectional, synchronously-triggered seismo-turbidites and debrites revealed by $\mathrm{X}$-ray computed tomography (CT). Sedimentology 61, 861-880.

Yelles, K., Lammali, K., Mahsas, A., Calais, E., Briole, P., 2004. Coseismic deformation of the May $21 \mathrm{st}, 2003, \mathrm{Mw}=6.8$ Boumerdes earthquake, Algeria, from GPS measurements. Geophys. Res. Lett. 31, L13610, doi:10.1029/2004GL019884.

Yelles A.K., Domzig, A., Déverchère, J., Bracène, R., Mercier de Lépinay, B., Strzerzynski, P., Bertrand, G., Boudiaf, A., Winter, T., Kherroubi, A., Le Roy, P., Djellit, H., 2009. PlioQuaternary reactivation of the Neogene margin off NW Algiers, Algeria: The Khayr al Din bank. Tectonophysics, doi:10.1016/j.tecto.2008.11.030. 
Zàruba, O., Mencl, V., 2014. Landslides and their control (2nd edition). Developments in Geotechnical Engineering, vol. 31, 324 pp., Elsevier Sci. Pub. Co., ISBN 9780444600769, Amsterdam, The Netherlands. 


\section{List of tables}

Table 1. List of cores, location (lat, Long), water depth, lengths and regional setting. KMDJ18, KMDJ20 and IMDJ20 were collected in 2005 during MARADJA2 survey onboard the N/O Suroit, PSM-KS21, PSM-KS23 and PSM-KS27 were collected in 2007 during the Prisme survey onboard the N/O Atalante.

Table 2. List of radiocarbon ages obtained on the core dataset. Lab code "SacA" indicates measurements done by Artemis (LMC14 Laboratory, Saclay, France) and Lab code "Poz" indicates measurements done by Poznan Radiocarbon Laboratory (Poland). Age min and age max correspond to the calibrated ages $2 \sigma$ (CAL BP) calculated by CALIB program with the calibration curve Marine 13 (Reimer et al., 2013), with a reservoir age of $400 \mathrm{yr}$.

\section{List of figures}

Figure 1. Location map of the algerian margin showing bathymetry and topography (isobaths every $500 \mathrm{~m}$ ), main historical earthquakes are indicated by red circles (after Domzig, 2006) and dark red circles for the earthquakes mentioned in this study.

Figure 2. Bathymetric map focused on the Algiers Area (isobaths each $500 \mathrm{~m}$ ), location of the main tectonic structures (modified after Domzig et al. 2006 and Strzerzynski et al. 2012) and data location (yellow dots for cores and white lines for seismic profiles used in this study).

Figure 3. Interpreted map of the turbidity currents generated by the Boumerdès earthquake in May 2003, derived from the backscatter imagery and cable breaks locations (after 
Cattaneo et al., 2011). Red line are communications cables with symbols indicating breaks, red points are the location of seismic aftershocks of the 2003 event.

Figure 4. Zoom of the bathymetric map focused on the Algiers area (yellow dots for cores and white lines for seismic profiles used in this study ).

Figure 5. Seismic profiles Mdjs24 and Mdjs25 across the lower part of the submarine slope of the margin and the interpretation (line-drawing). Approximated core locations are projected on the two profile (in red).

Figure 6. Sedimentological logs of the five cores, including the results of the radiocarbon dating (BP calibrated ages) and approximated timeline correlation for $3 \mathrm{ka} \mathrm{BP,} 6 \mathrm{ka}$ BP, 9 ka BP and 20 ka BP.

Figure 7. Details of the four types of sedimentary facies illustrated by core X-rays images, photographs and sedimentological logs (vertical scale in $\mathrm{cm}$ and horizontal scale for grain size: $\mathrm{C}=$ clay, $\mathrm{SC}=$ silty clay, $\mathrm{S}=$ silt, $\mathrm{vf}=$ =very-fine sand, $\mathrm{f}=$ fine sand, $\mathrm{m}=$ medium sand, c=coarse sand).

Figure 8. Correlation panel of the 5 cores for the last $9 \mathrm{kyr}$, including the core photographs, the sedimentological logs indicating visual grain size (yellow and orange rectangles respectively indicate silty and sandy layers). To improve the visualization, the depth scale is adapted for each core (aligned on the horizon of the base of turbidite T40). The main turbidite sequences are highlighted with colors and gathered from 1 to 6 elementary turbidite deposits, numbered from $\mathrm{T} 1$ at the top (seafloor) to $\mathrm{T} 40$. Radiocarbon sample locations and corresponding ages are indicated.

Figure 9. Age models established with OxCal software for the 5 cores (OxCal v4.2.4 Bronk Ramsey (2013); r:5 Marine 13 marine curve (Reimer et al., 2013), k parameter at 1, $\mathrm{dR}=0+/-50)$. Red stars indicate radiocarbon dating points. Colours correspond to 
sedimentary sequences defined for the core correlation. See the turbidites numbers indicated in black.

Figure 10. (A) Details of the core correlation and (B) age models of the top of the cores, illustrating the identification of historical earthquakes in the last depositional units. Sedimentological logs and photographs are presented at the same vertical scale. Red stars indicate the radiocarbon sample locations and corresponding ages used in age models. Age models correspond to the upper part of the Oxcal models presented in Fig.7.(C) Sedimentological log of the short interval core IMDJ20, collected closed to the KMDJ20 site.

Figure 11. (A) Sedimentological logs of PSM-KS21 and PSM-KS27, radiocarbon ages (cal $\mathrm{BP}, 2 \mathrm{~s})$ acquired in the core in red and projected after correlation with other cores in blue, (B) Oxcal age models with all the dates indicated by blue and red stars of PSMKS21 and PSM-KS27. Turbidites are gathered by sequences identified by colors. New ages modelled with cores PSM-KS21 and PSM-KS27 are both presented (in blue and red in Fig. 12).

Figure 12. (A) Dates of the turbidites identified in the cores PSM-KS21 (in red) and PSMKS27 (in blue) over the last $9 \mathrm{kyr}$ (OxCal age models in Fig. 10). (B) Recurrence intervals between two events, calculated with the mean ages of events (red points). Event uncertainties are represented by grey bars (dark grey for overlaps). (C) Recurrence intervals based on the paleoseismological record obtained with the turbidite deposits in the western Algerian margin (after Ratzov et al., 2015), same representation as in (B). 
Table 1

\begin{tabular}{|c|c|c|c|c|c|}
\hline Core & Latitude & Longitude & $\begin{array}{l}\text { Water } \\
\text { depth }(m)\end{array}$ & $\begin{array}{l}\text { Length } \\
\text { (m) }\end{array}$ & Regional setting \\
\hline KMDJ18 & $\mathrm{N} 37^{\circ} 01.15^{\prime}$ & $\mathrm{E} \mathrm{03}^{\circ} 02.59^{\prime}$ & 2601 & 9.49 & $\begin{array}{l}\text { Base of the slope off Algiers - western } \\
\text { part of the Algiers ridge }\end{array}$ \\
\hline KMDJ20 & N 36 $59,05^{\prime}$ & $\mathrm{E} \mathrm{03}^{\circ} 19.69^{\prime}$ & 2342 & 9.45 & $\begin{array}{l}\text { Base of the slope - Outlet of the Algiers } \\
\text { canyon, southern side of the Algiers ridge }\end{array}$ \\
\hline $\begin{array}{l}\text { IMDJ20 } \\
\text { (Interface) }\end{array}$ & N 36 59,05' & $\mathrm{E} \mathrm{03}^{\circ} 19.69^{\prime}$ & 2342 & 0.78 & Same site as KMDJ20 \\
\hline PSM-KS21 & N 37 09.953' & $\mathrm{E} 02^{\circ} 42.127^{\prime}$ & 2779 & 12.68 & $\begin{array}{l}\text { Distal basin in front of Khayr Al Din } \\
\text { plateau }\end{array}$ \\
\hline PSM-KS23 & N 37 27.093' & $\mathrm{E} 02^{\circ} 59,526^{\prime}$ & 2775 & 11.98 & $\begin{array}{l}\text { Distal basin at } 60 \mathrm{~km} \text { from the base of the } \\
\text { slope. }\end{array}$ \\
\hline PSM-KS27 & N $37^{\circ} 18.102^{\prime}$ & $\mathrm{E} \mathrm{03}^{\circ} 24.317^{\prime}$ & 2791 & 13.34 & Distal basin in front of Algiers Canyon \\
\hline
\end{tabular}


Table 2

\begin{tabular}{|c|c|c|c|c|c|c|c|}
\hline Cores & $\begin{array}{l}\text { Sample } \\
\text { intervals } \\
\text { (cm) }\end{array}$ & Foram. species & Lab code & $\begin{array}{l}\text { Age } \\
14 C\end{array}$ & error & $\begin{array}{c}\text { Age } \\
\text { min } \\
\text { CAL BP }\end{array}$ & $\begin{array}{c}\text { Age } \\
\text { max } \\
\text { CAL BP }\end{array}$ \\
\hline KMDJ18 & $82-83$ & G. ruber & SacA 31861 & 2385 & 30 & 1920 & 2111 \\
\hline KMDJ18 & $286-287$ & G. ruber, G. sacculifer & SacA 31862 & 6645 & 30 & 7096 & 7258 \\
\hline KMDJ18 & $546-547$ & G. ruber, G. sacculifer & SacA 31863 & 9590 & 35 & 10358 & 10551 \\
\hline KMDJ20 & $122-123$ & G. ruber, G. sacculifer, G. bulloides & SacA 31864 & 2095 & 30 & 1569 & 1778 \\
\hline KMDJ20 & $247-248$ & G. ruber, G. sacculifer & SacA 31865 & 3700 & 30 & 3509 & 3712 \\
\hline KMDJ20 & $430-431$ & G. ruber, G. sacculifer & SacA 31866 & 6090 & 30 & 6425 & 6617 \\
\hline IMDJ20 & $57-58$ & G. ruber, G. sacculifer, G. bulloides & SacA 31867 & 1680 & 30 & 1167 & 1296 \\
\hline PSM-KS21 & $27-28$ & G. ruber, G. sacculifer, G. bulloides & Sac 29242 & 1185 & 30 & 658 & 794 \\
\hline PSM-KS21 & $62-63$ & G. ruber, G. sacculifer, G. bulloides & SacA 21673 & 2265 & 30 & 1789 & 1966 \\
\hline PSM-KS21 & $126-127$ & G. ruber, G. sacculifer & SacA 21674 & 3045 & 30 & 2737 & 2895 \\
\hline PSM-KS21 & $165-166$ & G. Ruber & SacA40806 & 3700 & 30 & 3509 & 3712 \\
\hline PSM-KS21 & $276-277$ & G. ruber, G. sacculifer & SacA 21675 & 6050 & 30 & 6383 & 6568 \\
\hline PSM-KS21 & $417,5-419$ & G. Ruber & SacA 40807 & 8590 & 40 & 9114 & 9388 \\
\hline PSM-KS21 & $837-838$ & G. Ruber & Poz-68081 & 16790 & 90 & 19383 & 19881 \\
\hline PSM-KS23 & $19-20$ & G. Ruber & SacA 29343 & 1575 & 30 & 1049 & 1227 \\
\hline PSM-KS23 & $54-55$ & G. ruber, G. sacculifer + oth pl & Poz-34066 & 3485 & 35 & 3268 & 3454 \\
\hline PSM-KS23 & $78-79$ & G. ruber, G. sacculifer & SacA 21676 & 4935 & 30 & 5133 & 5410 \\
\hline PSM-KS23 & $114-116$ & G. ruber, G. sacculifer + oth $p l$ & Poz-34031 & 7760 & 60 & 8074 & 8362 \\
\hline PSM-KS23 & $140-142$ & G. ruber, G. sacculifer + oth pl & Poz-34067 & 8500 & 50 & 8994 & 9270 \\
\hline PSM-KS23 & $423-424,5$ & G. Ruber & Poz-68119 & 15270 & 80 & 17806 & 18521 \\
\hline PSM-KS27 & $34-35$ & G. Ruber, G. Sacculifer & SacA 29339 & 990 & 30 & 519 & 636 \\
\hline PSM-KS27 & $114-115$ & G. Ruber & SacA 40808 & 1495 & 30 & 954 & 1138 \\
\hline PSM-KS27 & $179-180$ & G. Ruber & SacA 29340 & 2835 & 30 & 2475 & 2702 \\
\hline PSM-KS27 & $234-235$ & G. Ruber & SacA 40229 & 3605 & 30 & 3403 & 3575 \\
\hline PSM-KS27 & 308-309 & G. Ruber & SacA 29341 & 5400 & 30 & 5681 & 5875 \\
\hline PSM-KS27 & $460-461$ & G. Ruber & SacA 40809 & 8440 & 35 & 8967 & 9185 \\
\hline PSM-KS27 & $1302,5-1305$ & G. Ruber & SacA 40227 & 20230 & 100 & 23314 & 24008 \\
\hline
\end{tabular}




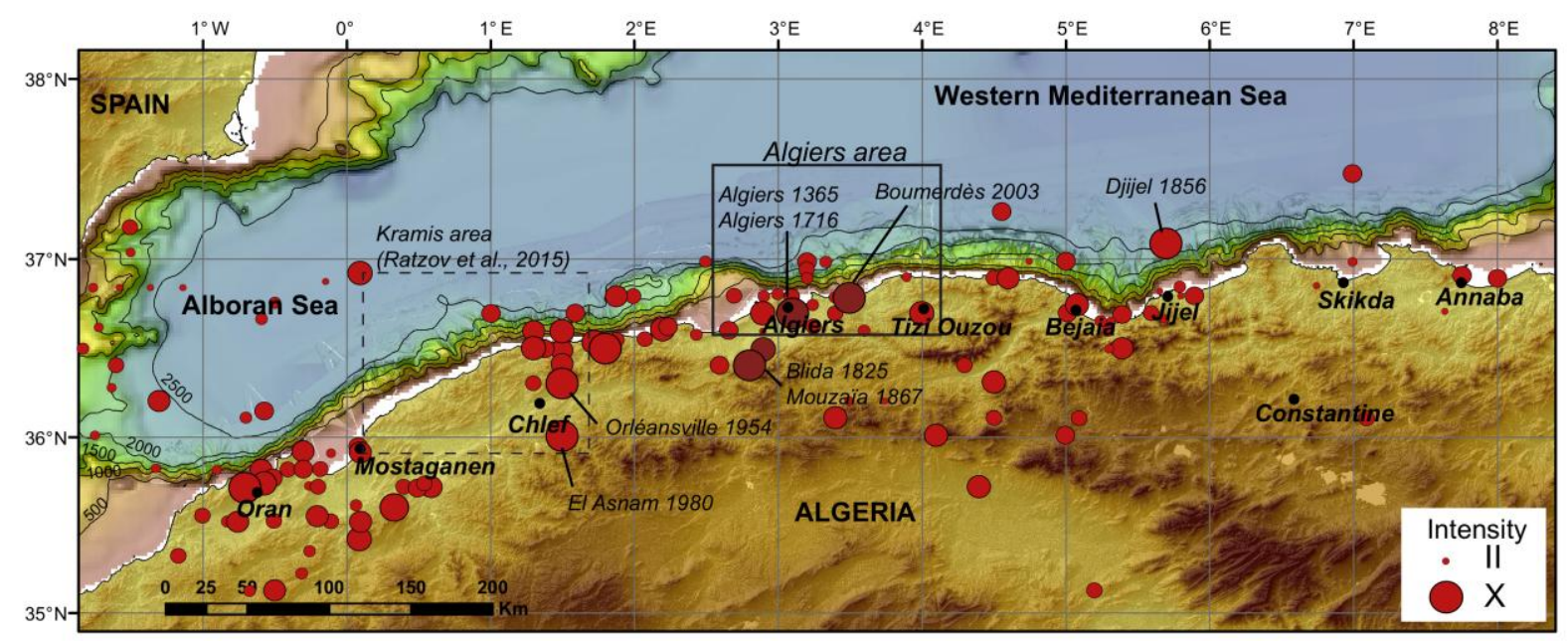

Figure 1 


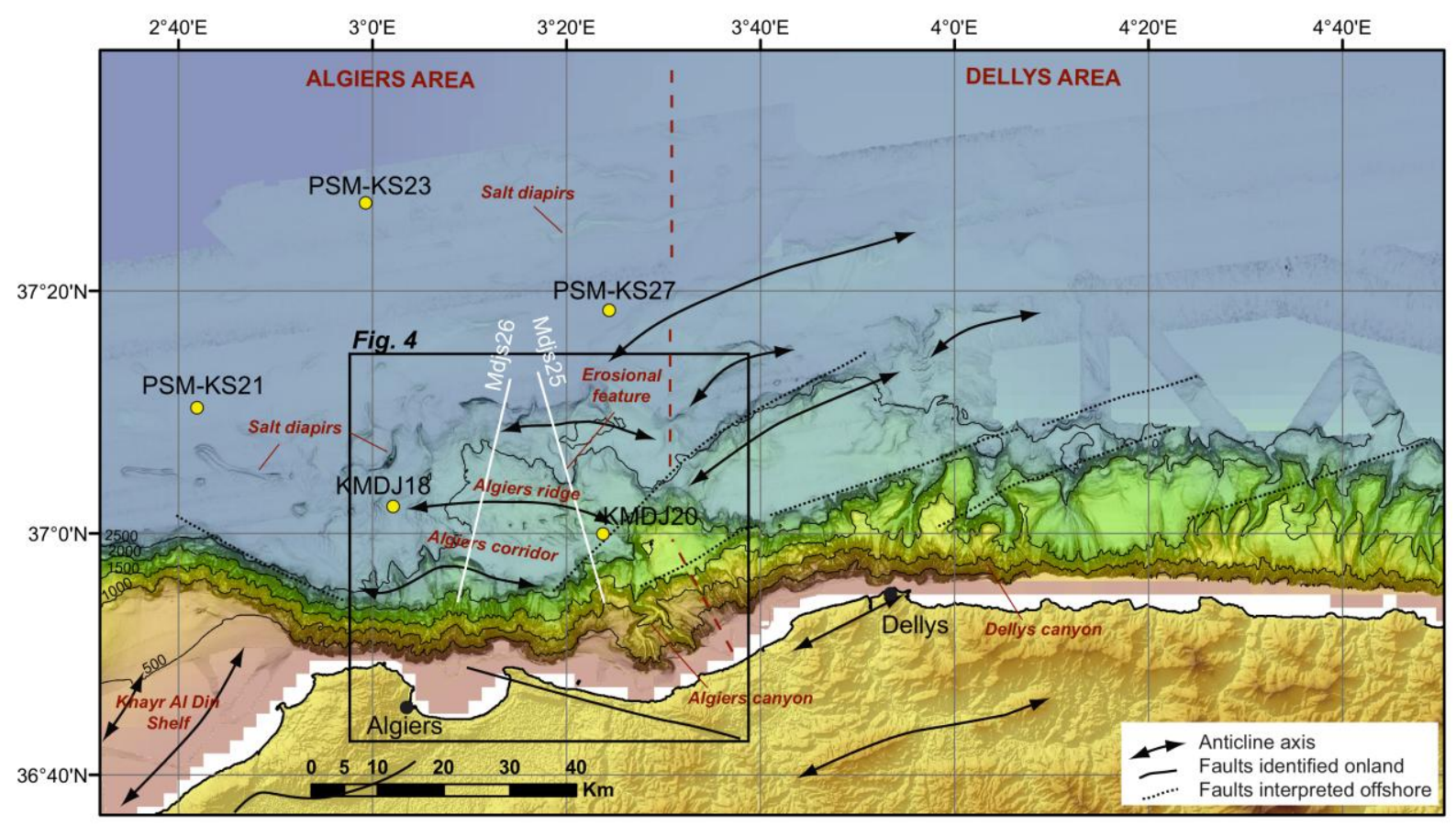

Figure 2 


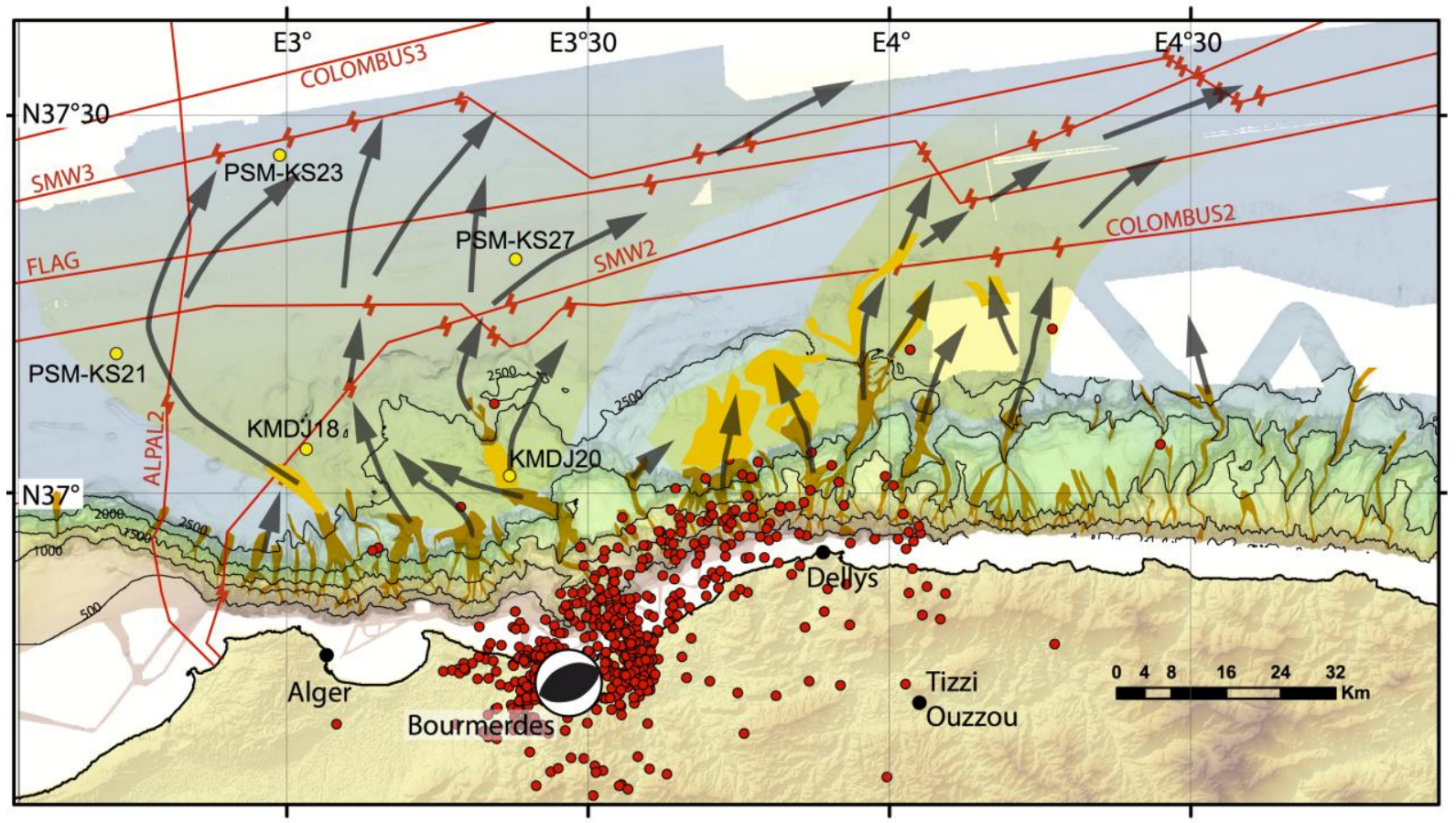

Figure 3 


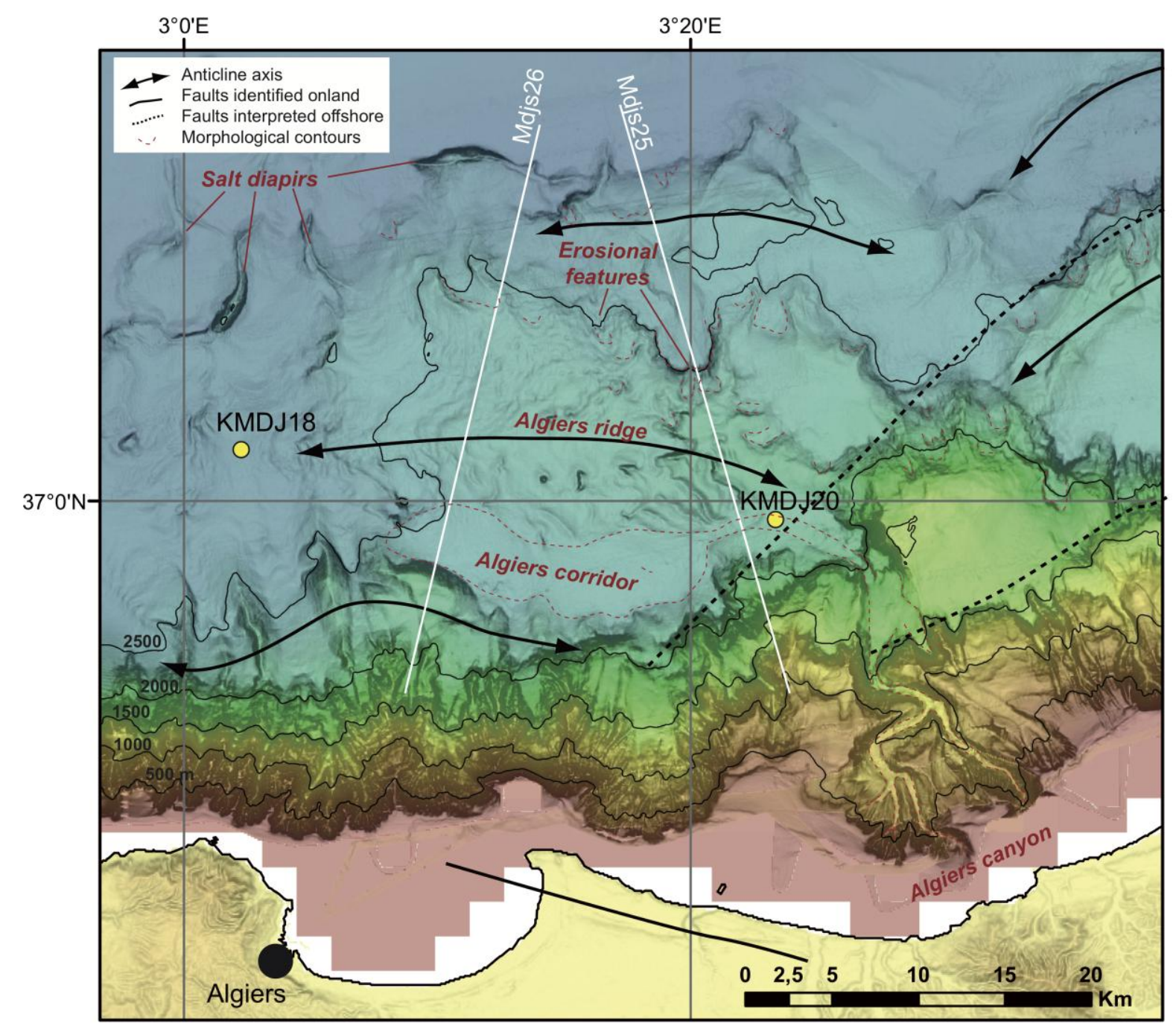

Figure 4 

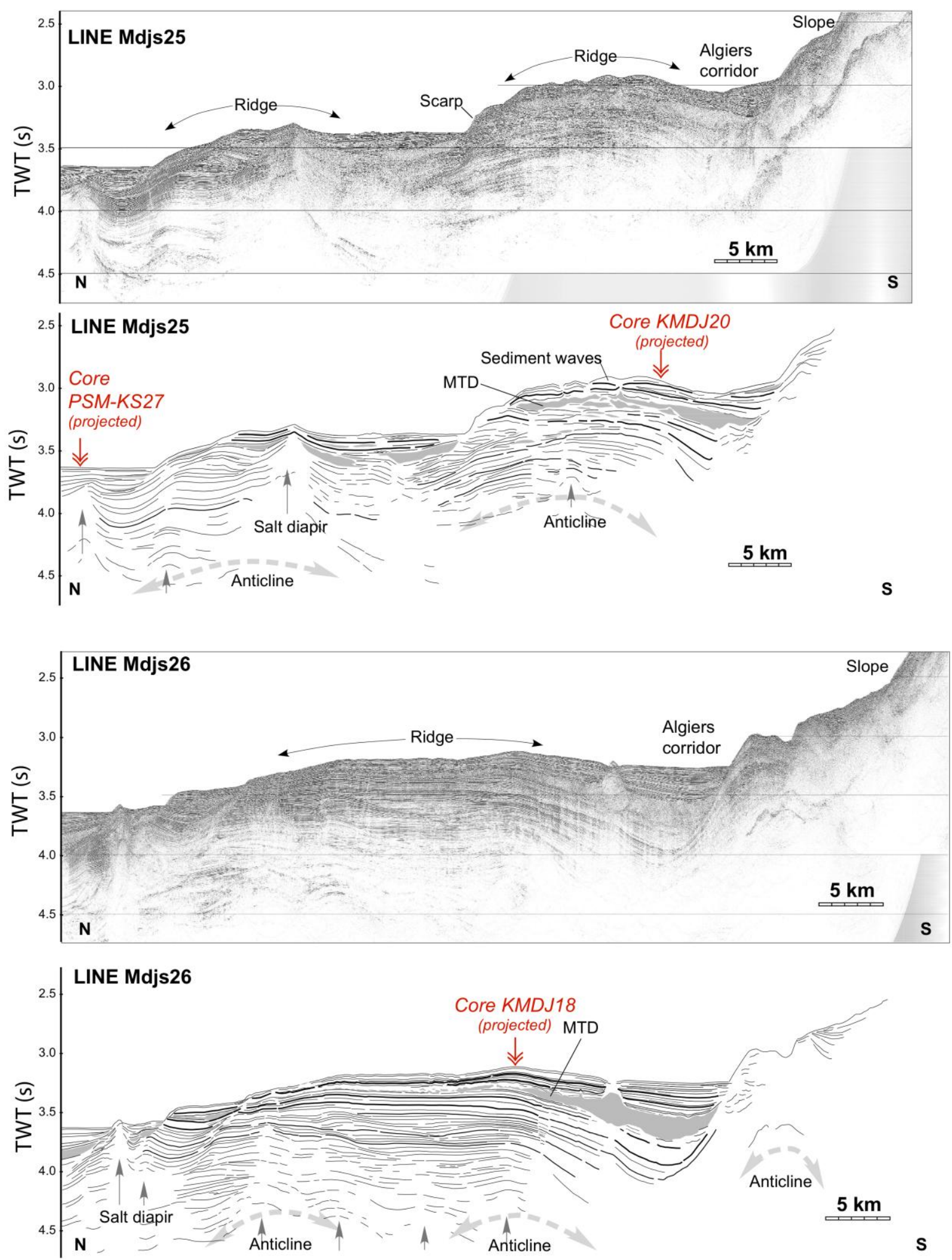

Figure 5 


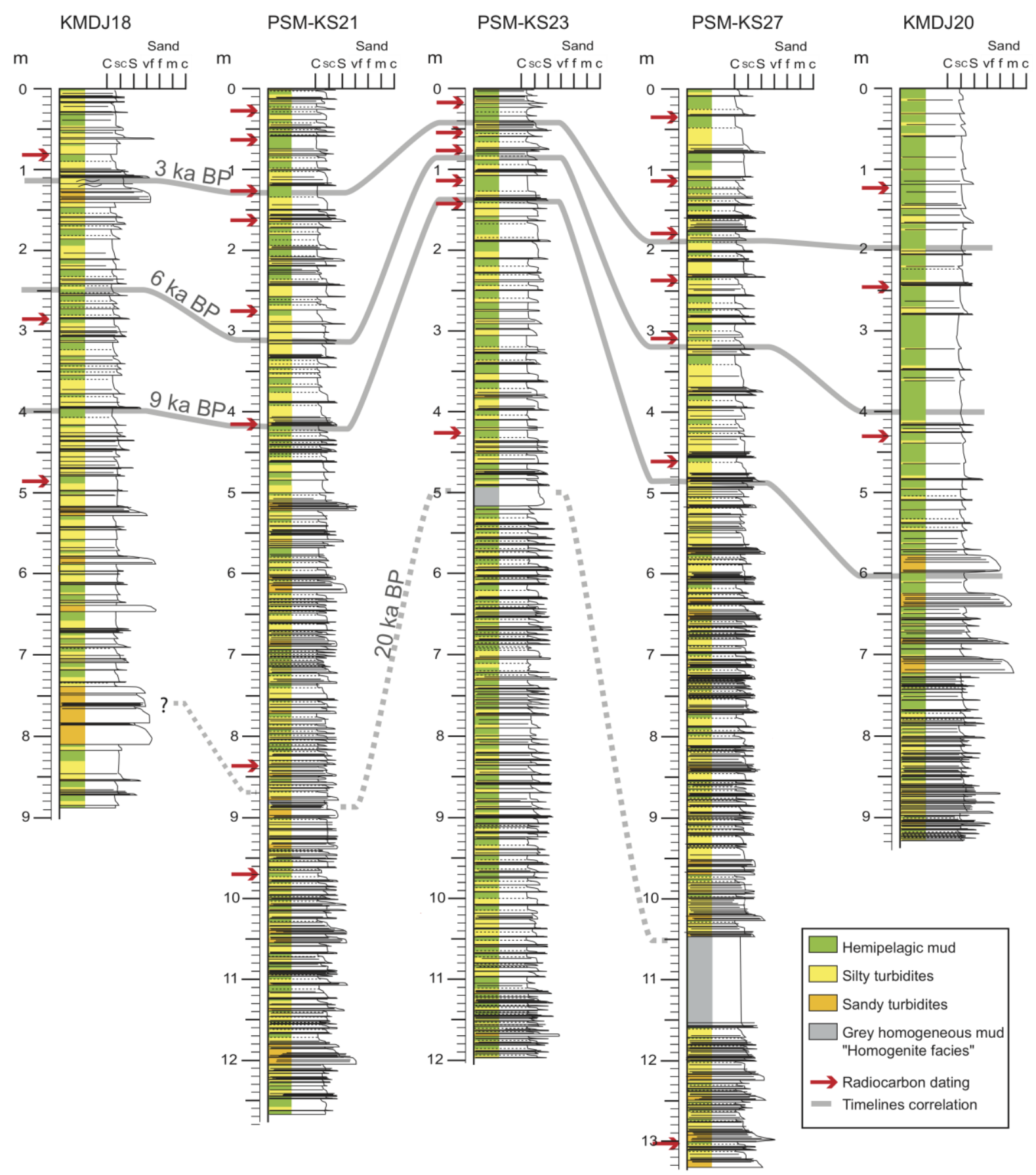

Figure 6 


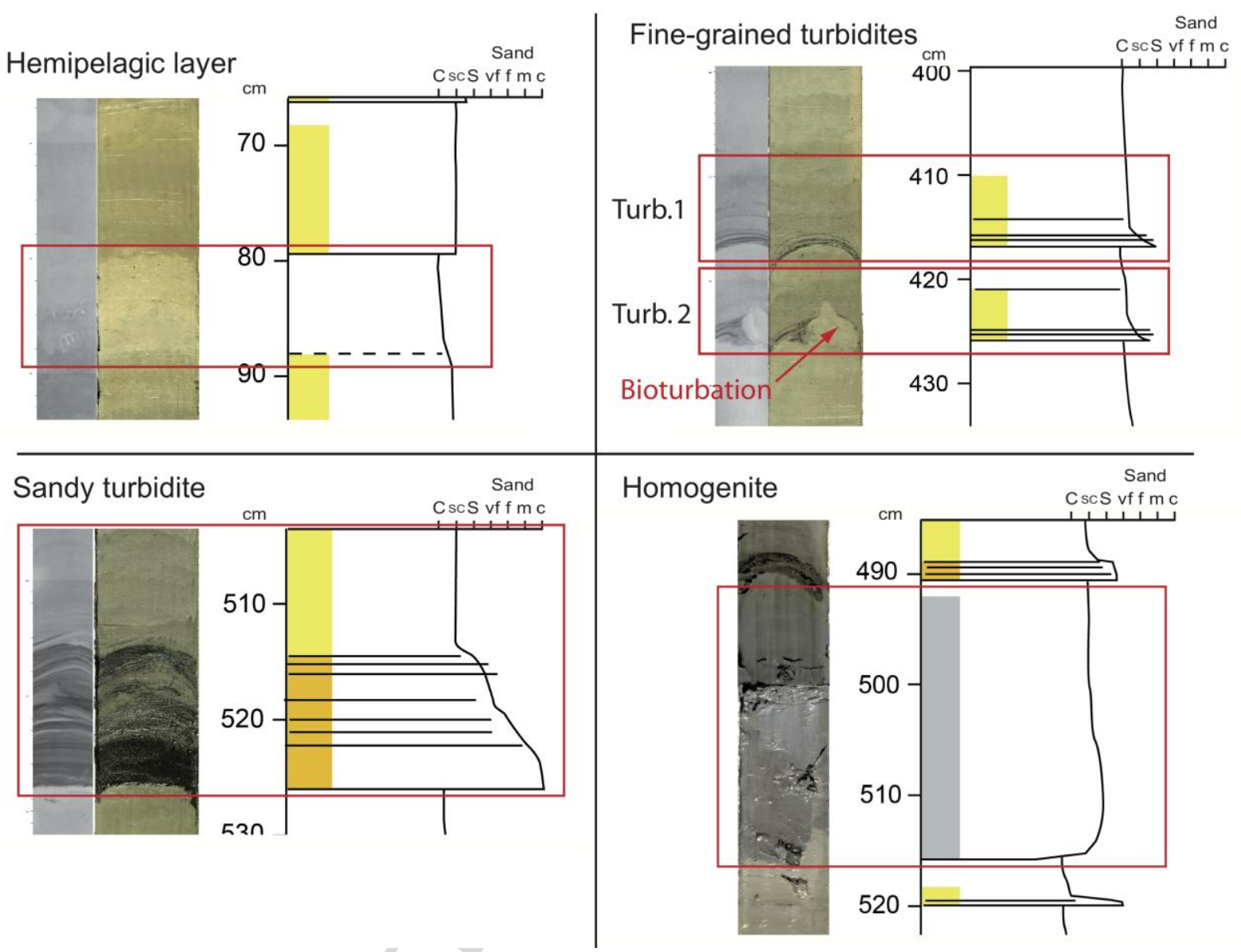

Figure 7 


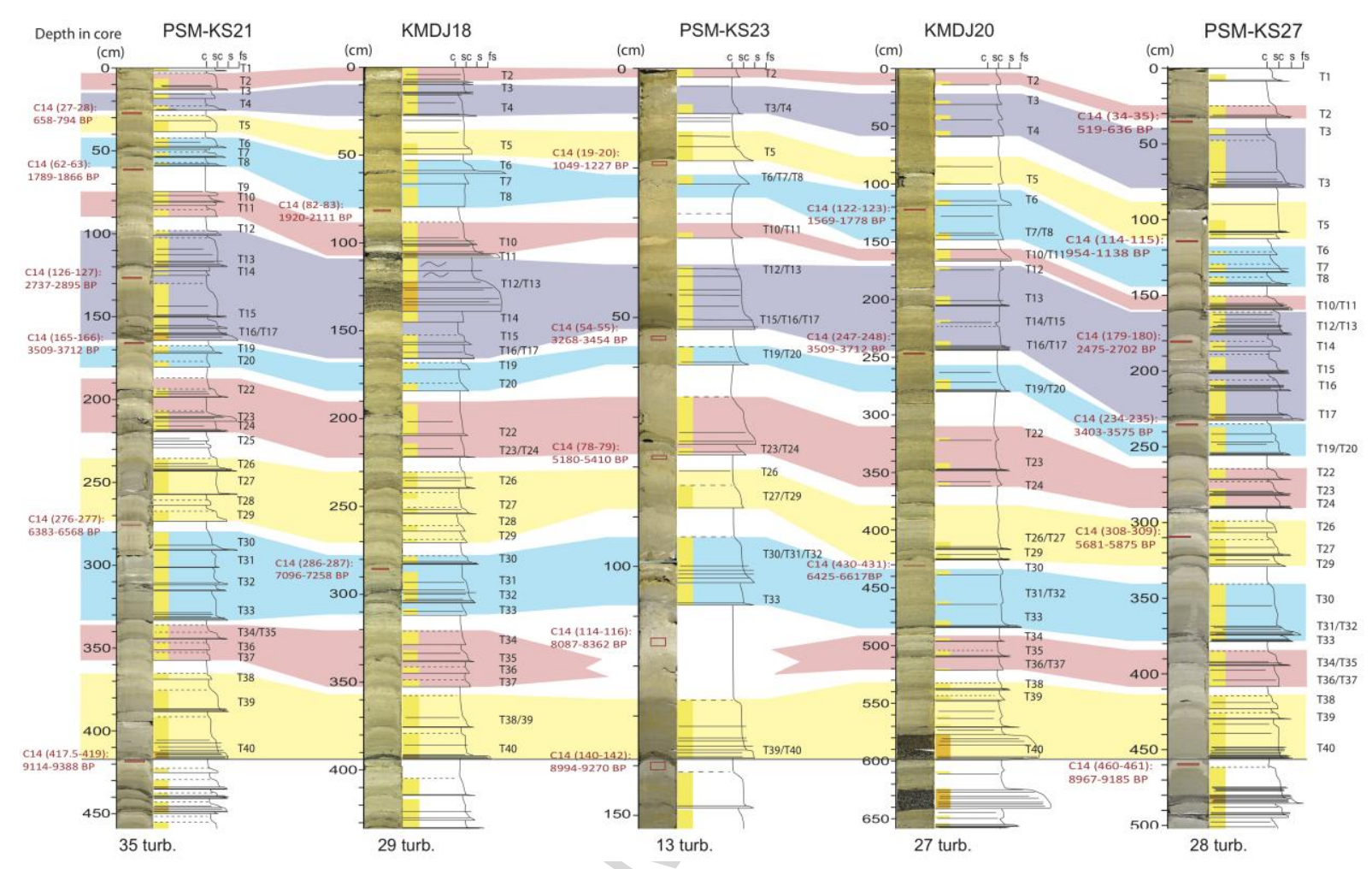

Figure 8 

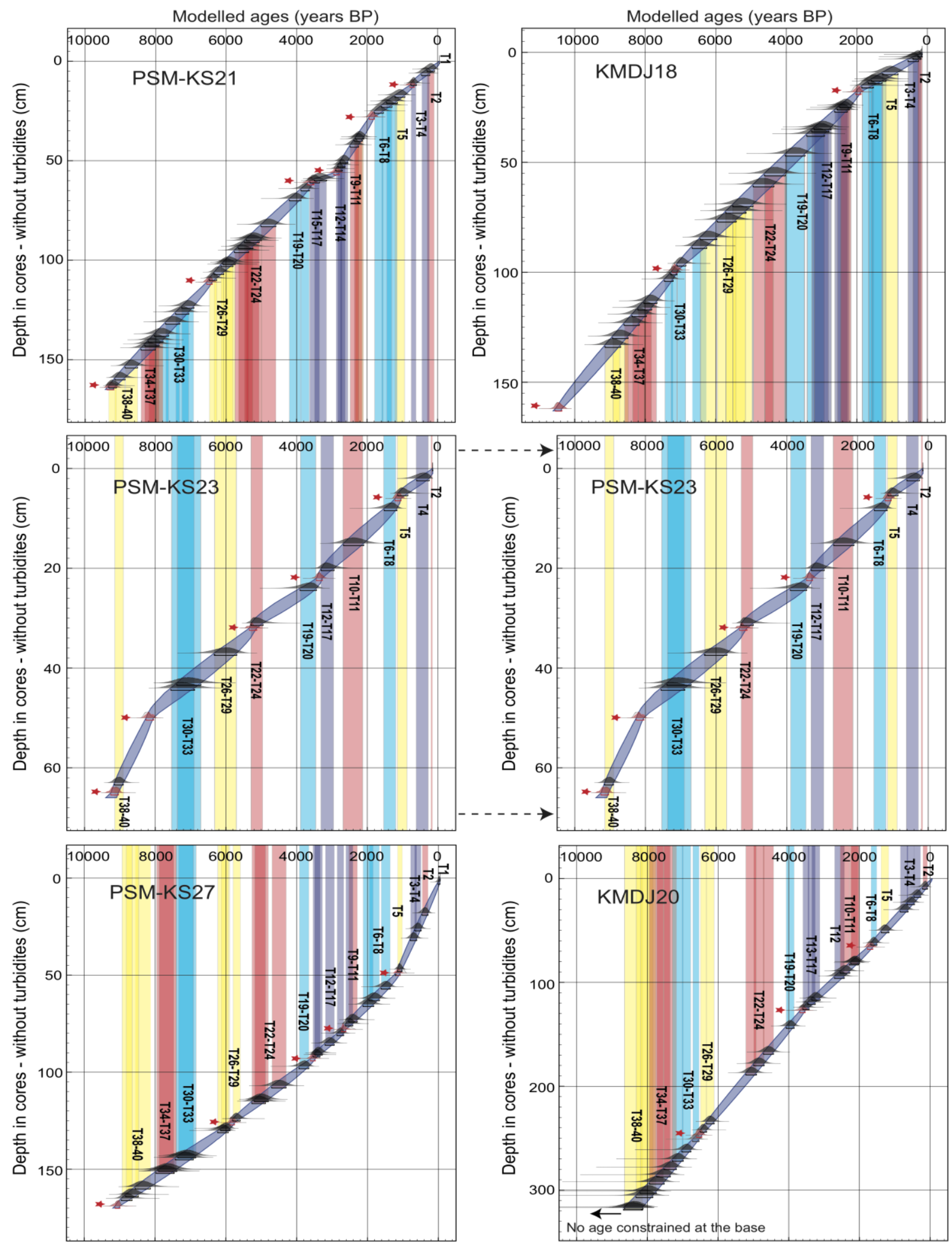

Figure 9 


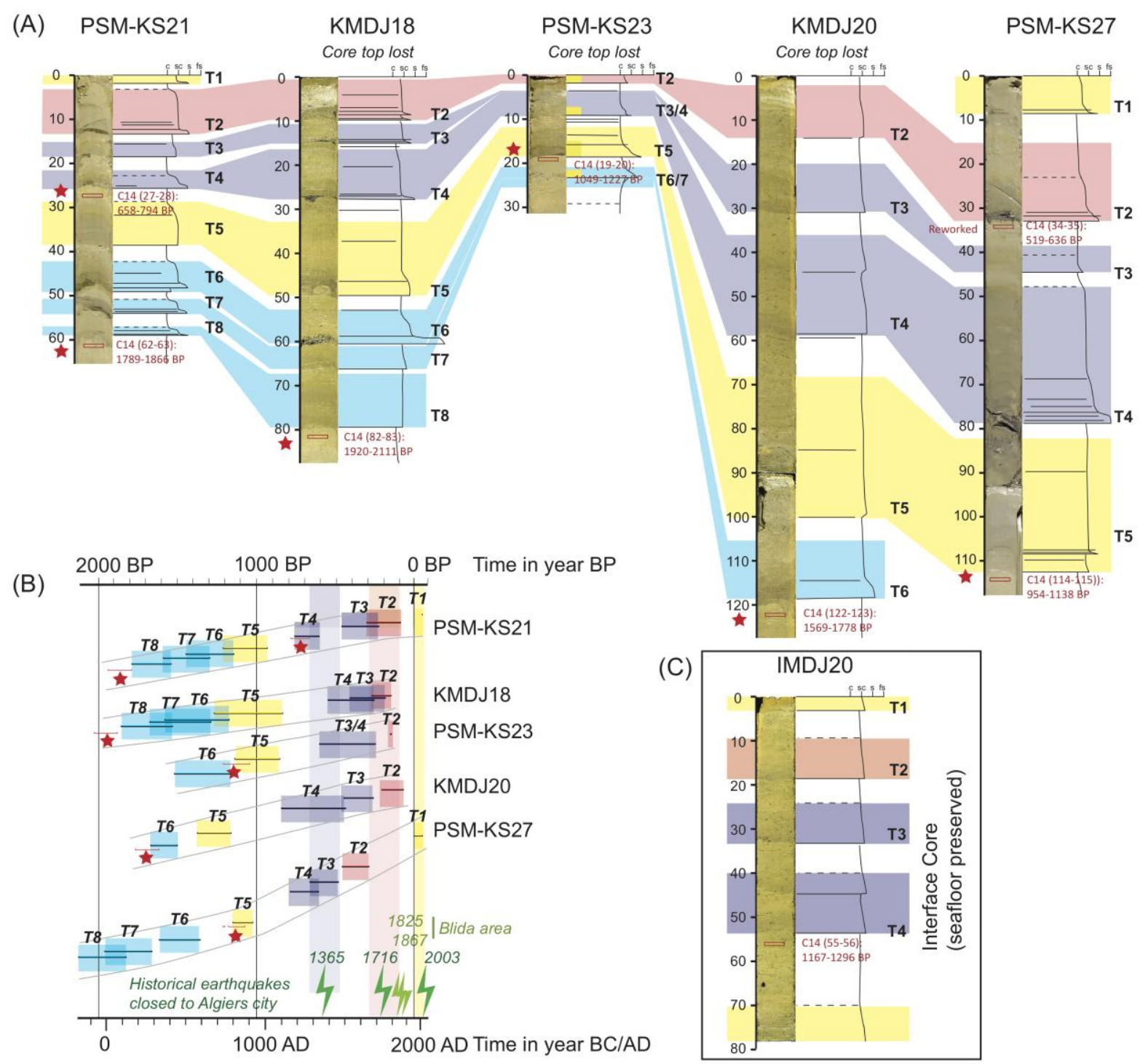

Figure 10 
(A)

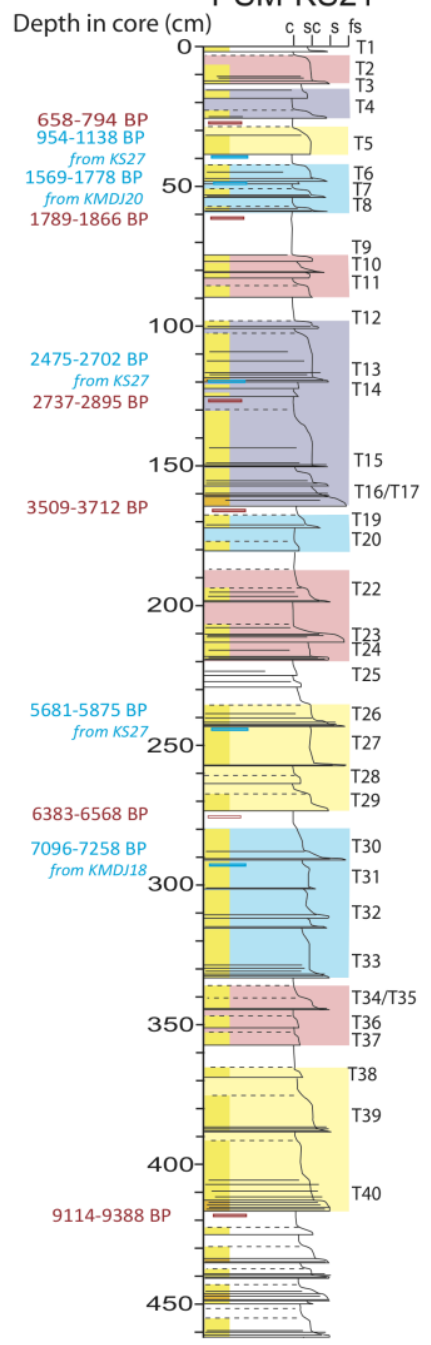

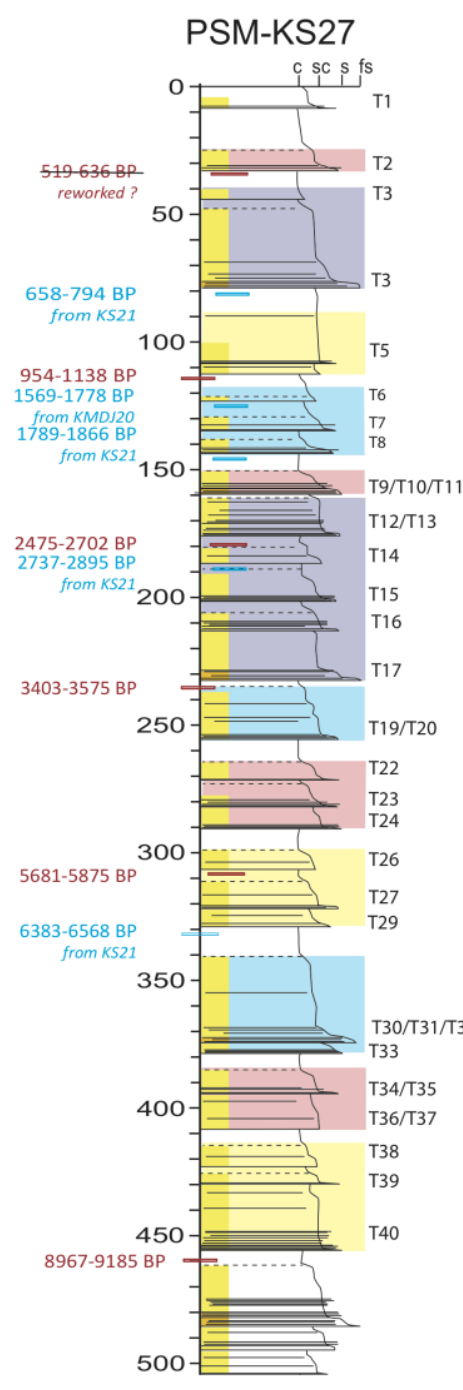
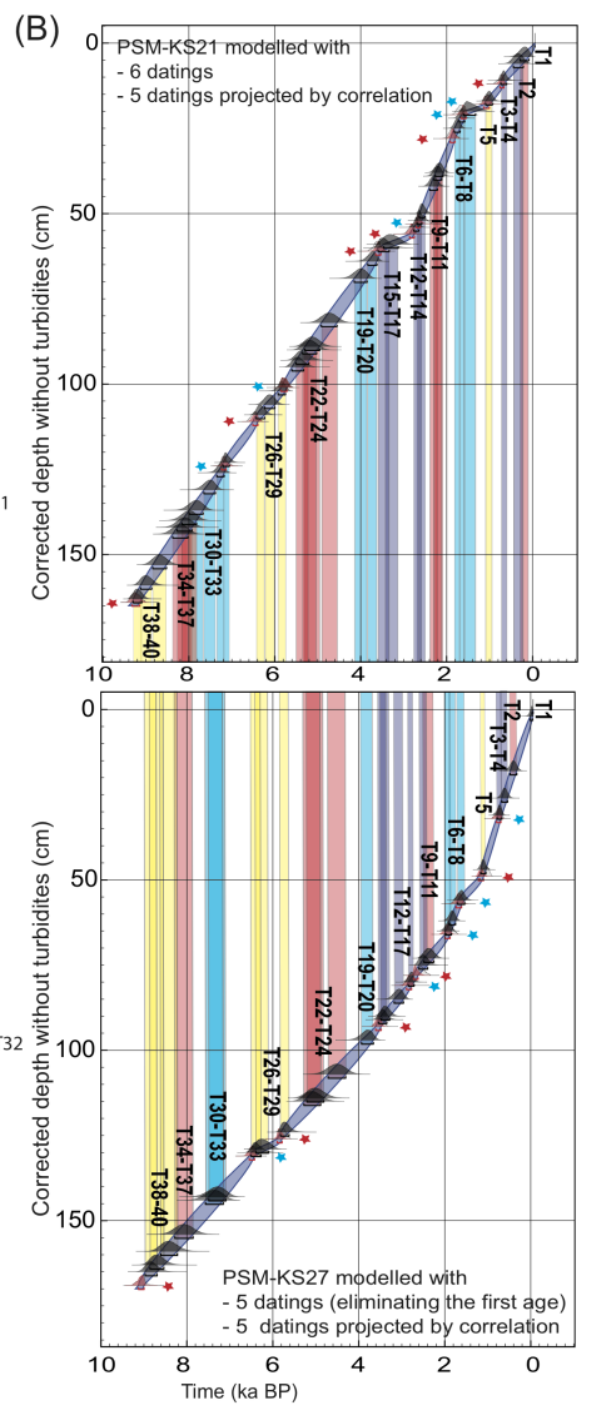

Figure 11 

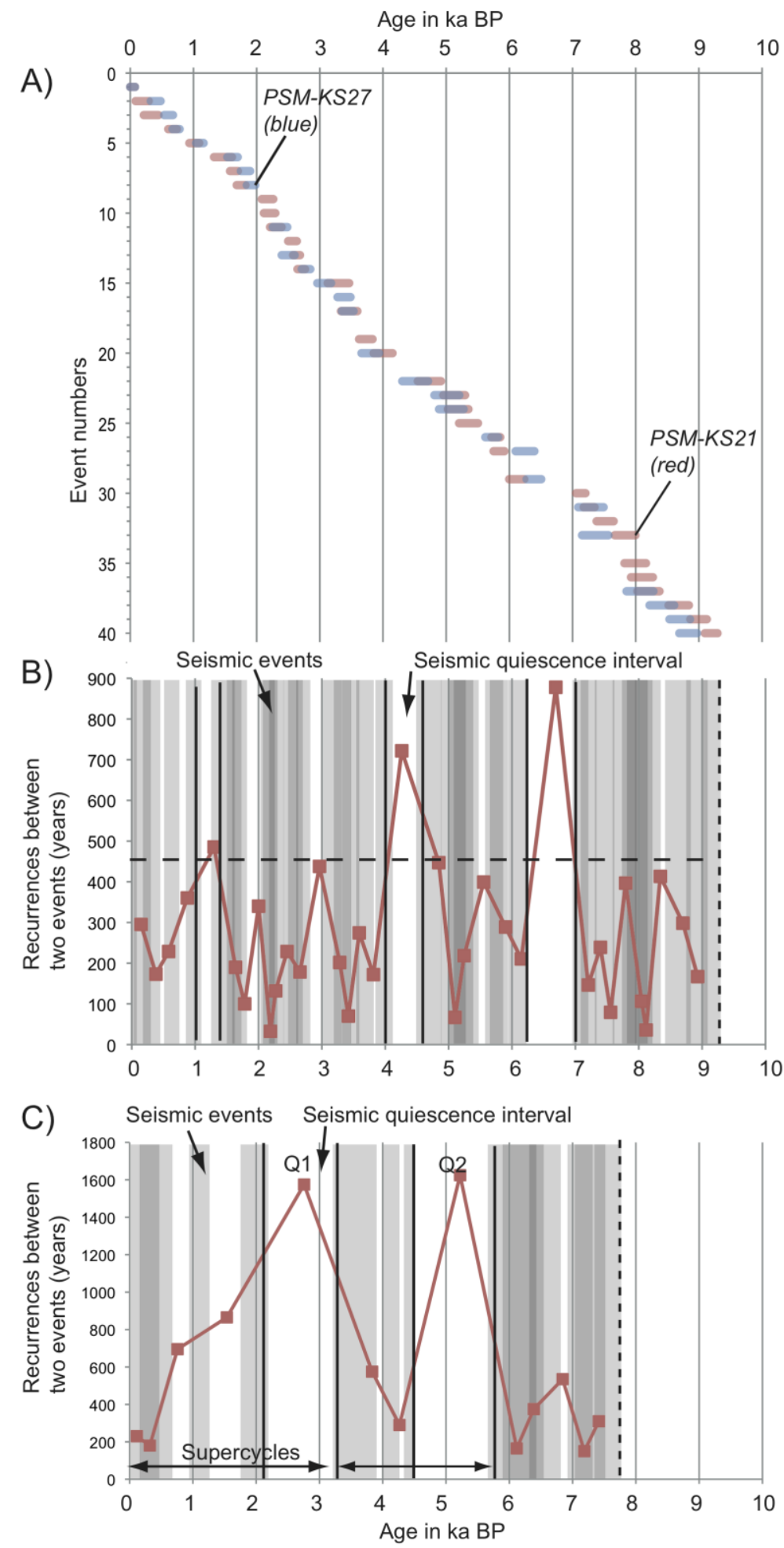

Figure 12 